\title{
KARAKTERISTIK TEKANAN LUAP DAN PENYEBABNYA PADA DAERAH LEPAS PANTAI SELAT MADURA
}

\author{
YUDHA RISNANDAR SINULINGGA ${ }^{1}$, AGUS MOCHAMMAD RAMDHAN ${ }^{2}$
}

1. SKK MIGAS, Gd. Wisma Mulia Lantai 23, Jl. Jend. Gatot Subroto No.42 Jakarta, 12710, Jakarta. Email: yrsinulingga@skkmigas.go.id.

2. Program Studi Teknik Geologi, Fakultas Ilmu dan Teknologi Kebumian, Institut Teknologi Bandung

(ITB), Jl. Ganesha No.10, Bandung, Jawa Barat, Indonesia, 40132.

\begin{abstract}
Sari - Cekungan Jawa Timur merupakan salah satu cekungan hirokarbon yang prolifik berumur Tersier di Indonesia. Cekungan ini juga dikenal memiliki sifat tekanan luap yang sering menyebabkan terjadinya kendala pada saat proses pemboran. Gejala tekanan luap pada cekungan ini lazim ditemui pada formasi yang berumur PlioPleistosen pada daerah dalaman dimana sedimen terendapkan secara cepat. Analisis terhadap data log talikawat, data pengukuran tekanan formasi secara langsung, berat lumpur pemboran dan drilling events pada sumur eksplorasi lepas pantai di Selat Madura dilakukan guna mengetahui karakteristik gejala tekanan luap. Metoda Eaton dan Metode Swarbrick digunakan untuk melakukan estimasi besaran tekanan luap pada daerah riset. Letak daerah penelitian secara fisiografis yang berada Kendeng Trough yang merupakan kelanjutan zona depresi KendengRandublatung yang memanjang ke arah barat-timur memungkinkan terjadinya proses sedimentasi terjadi sangat cepat sehingga mengendapkan sedimen yang tebal. Proses sedimentasi yang sangat cepat ini diasumsikan akan menyebabkan gagalnya fluida formasi keluar dari pori batuan pada saat proses kompaksi berlangsung.
\end{abstract}

Kata kunci: Tekanan Luap, pemboran, Plio-Pleistosen, metode Eaton, Metode Swarbrick

\begin{abstract}
The East Java Basin is known as one of the prolific Tertiary hydrocarbon basin. This basin is also well known for its overpressure characteristic which occurs as a problem in drilling activity. Overpressure in East Java Basin generally occurs in Plio-Pleistocene interval which deposited in depression by rapid sedimentation rate. Wireline logs, pressure direct measurements, drilling mudweight and drilling events from four offshore exploration wells in Madura Strait are analysed to study overpressure characteristics and its mechanism. Eaton's and Swarbrick's Method are used to estimate the magnitude of pore pressure in research area. The location of research area within Kendeng Trough that physiographycally is a continuation of Kendeng-Randublatung Depression to the east might cause rapid sedimentation of thick sediment that would led to the generation of overpressure .
\end{abstract}

Keywords: Overpressure, drilling, Plio-Pleistosen, Eaton metode, Swarbrick Metode

\section{PENDAHULUAN}

Cekungan Jawa Timur Utara telah dikenal sebagai salah satu cekungan hidrokarbon prolific sejak abad ke-19. Hidrokarbon telah diproduksi di cekungan ini sejak tahun 1887. Hingga saat ini Cekungan Jawa Timur Utara telah menghasilkan sekitar 220 juta barel hidrokarbon (Pertamina BPPKA, 1996).
Kegiatan eksplorasi di Cekungan Jawa Timur tidak terlepas dari kendala-kendala yang dijumpai selama pengeboran. Salah satu kendala yang menjadi tantangan dalam kegiatan eksplorasi di Cekungan Jawa Timur adalah adanya kehadiran tekanan luap. Kehadiran tekanan luap di cekungan 
ini telah cukup lama menjadi perhatian pengeboran. Sebagai contoh, beberapa sumur di selatan Surabaya memiliki gejala tekanan luap berupa litologi serpih yang mengalami tekanan luap. Akibatnya sumursumur tersebut akhirnya ditinggalkan.

Gejala tekanan luap dapat diamati di permukaan melalui manisfestasi berupa adanya gunung lumpur (Satyana dan Asnidar, 2008). Satyana dan Asnidar (2008) menyebutkan bahwa lokasi gunung api lumpur dan diapir berada pada jalur Depresi Bogor-Serayu Utara-Kendeng-Selat Madura. Batuan sedimen berumur Pliosen dan Pleistosen di daerah ini terendapkan secara cepat ke dalam cekungan dan terkompresi dengan intensif akibat konvergensi Pulau Jawa. Berdasarkan penelitian diketahui bahwa mekanisme pembentukan gunung api lumpur Ciuyah di Kuningan (Jawa Barat), diapir Serayu Utara (Jawa Tengah Utara), dan lainnya terkait sistem elisional. Kehadiran tekanan luap akan menentukan tingkat keberhasilan suatu kegiatan pengeboran. Apabila gejala tekanan luap karena dapat berdampak pada sumur tidak diidentifikasi dengan baik, maka bukan tidak mungkin akan timbul kendala-kendala teknis seperti guguran serpih, rangkaian pipa pengeboran yang terjepit, hingga yang terburuk yaitu terjadinya blow out.

Penelitian ini dilakukan untuk menganalisis karakteristik tekanan luap yang meliputi mekanisme pembentukan, penyebarannya, dan hubungannya dengan karakteristik geologi maupun geofisika di area penelitian. Pengetahuan mengenai karakteristik tekanan luap di daerah penelitian sangat penting implikasinya bagi kelancaran operasional pengeboran eksplorasi. Karena tidak jarang, tekanan luap menyebabkan terjadinya masalah operasional yang memicu penambahan Non Productive Time dari kegiatan pengeboran, sehingga cukup merugikan bagi kontraktor migas di daerah ini. Hasil penelitian ini diharapkan dapat menjadi bahan pertimbangan dalam perencanaan kegiatan pengeboran di Daerah Selat Madura (Gambar 1) di masa yang akan datang.

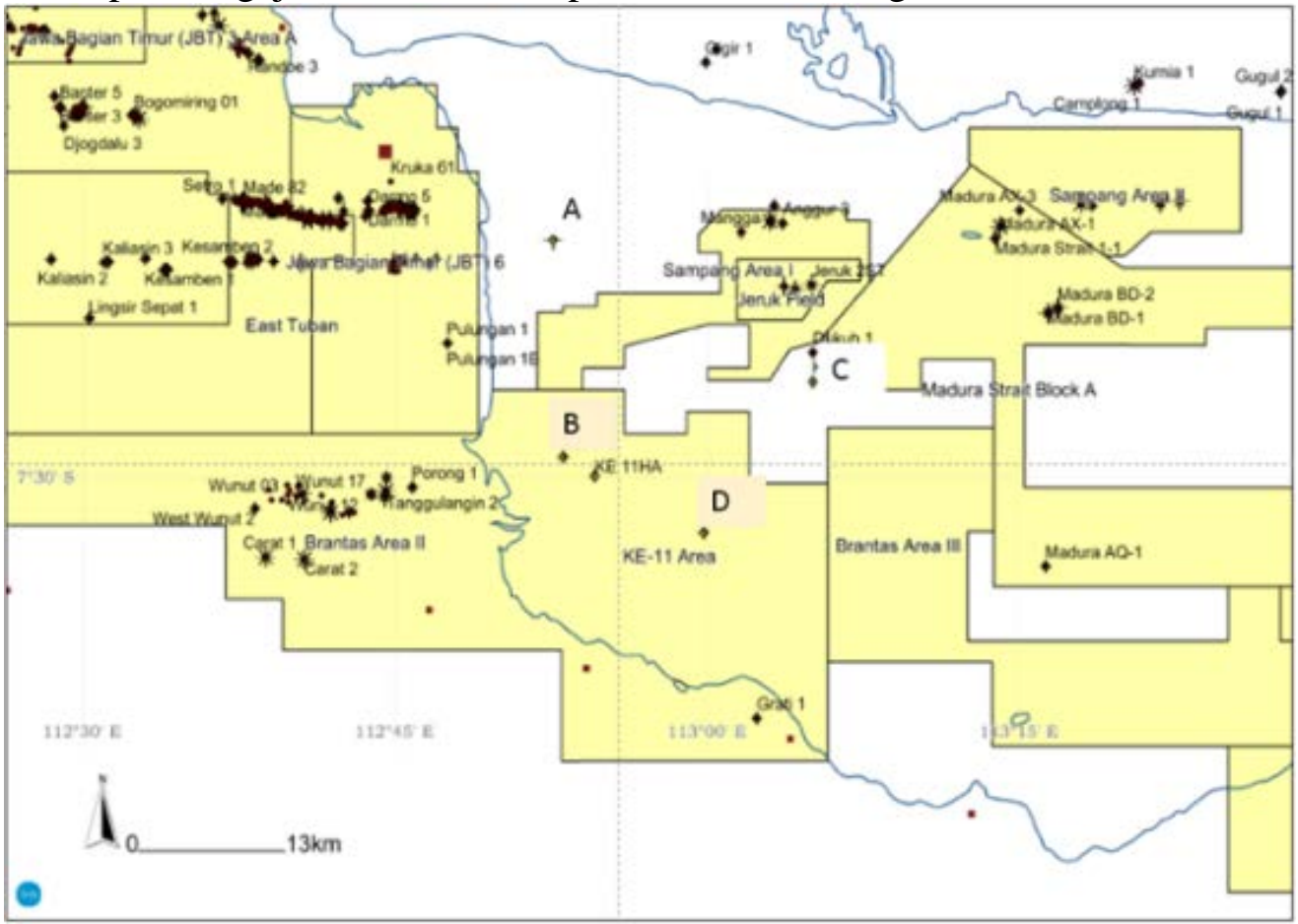

Gambar 1. Lokasi daerah penelitian di Selat Madura (Modifikasi dari Heidbach dkk., 2009). 

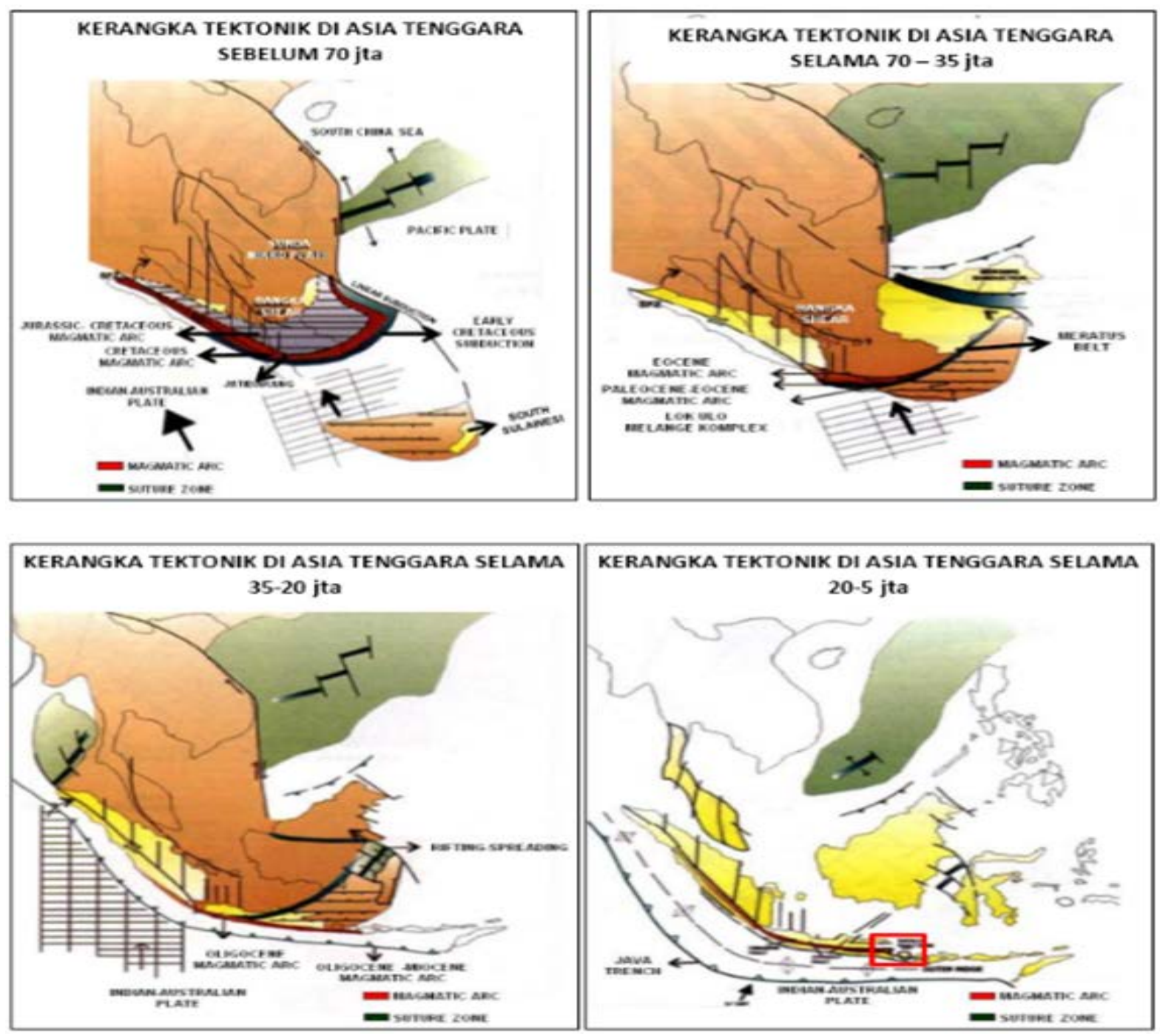

Gambar 2. Evolusi tektonik di kawasan Indonesia bagian barat (Sribudiyani dkk., 2003).

\section{TEKTONIK REGIONAL}

Keranka tektonik Pulau Jawa saat ini merupakan hasil dari interaksi tektonik yang terjadi pada Mesozoik Akhir hingga Tersier (Sribudiyani dkk, 2003). Kerangka tektonik area ini merupakan hasil dari pergerakan Lempeng Eurasia, Lempeng Indo-Australia, dan Lempeng Philipina-Pasifik (Bransden dan Matthews, 1992). Evolusi tektonik di wilayah Indonesia bagian barat (Gambar 2) dimulai sejak Kapur Akhir-Eosen Awal. Pecahan benua yang berasal dari Super Benua Gondwana bergerak dari selatan ke utara dan membentuk kompleks penunjaman (Lok Ulo-Meratus).
Bersatunya pecahan benua ini dengan Lempeng Eurasia menyebabkan terjadinya aktifitas magma pada umur Eosen dan terus berlanjut sampai aktifitas magma menurun. Komplek penunjaman kemudian terangkat dan membentuk Pegunungan Meratus di bagian timur Pulau Kalimantan serta komplek batuan bancuh (melange) Lok Ulo di Jawa Tengah. Struktur batuan dasar ini mempengaruhi orientasi cekungan. Dibagian timur dari Cekungan Jawa Timur, struktur batuan dasar yang terbentuk berarah barat timur yang dapat dikenali dari sumur-sumur di Cekungan Kendeng dan Madura. 


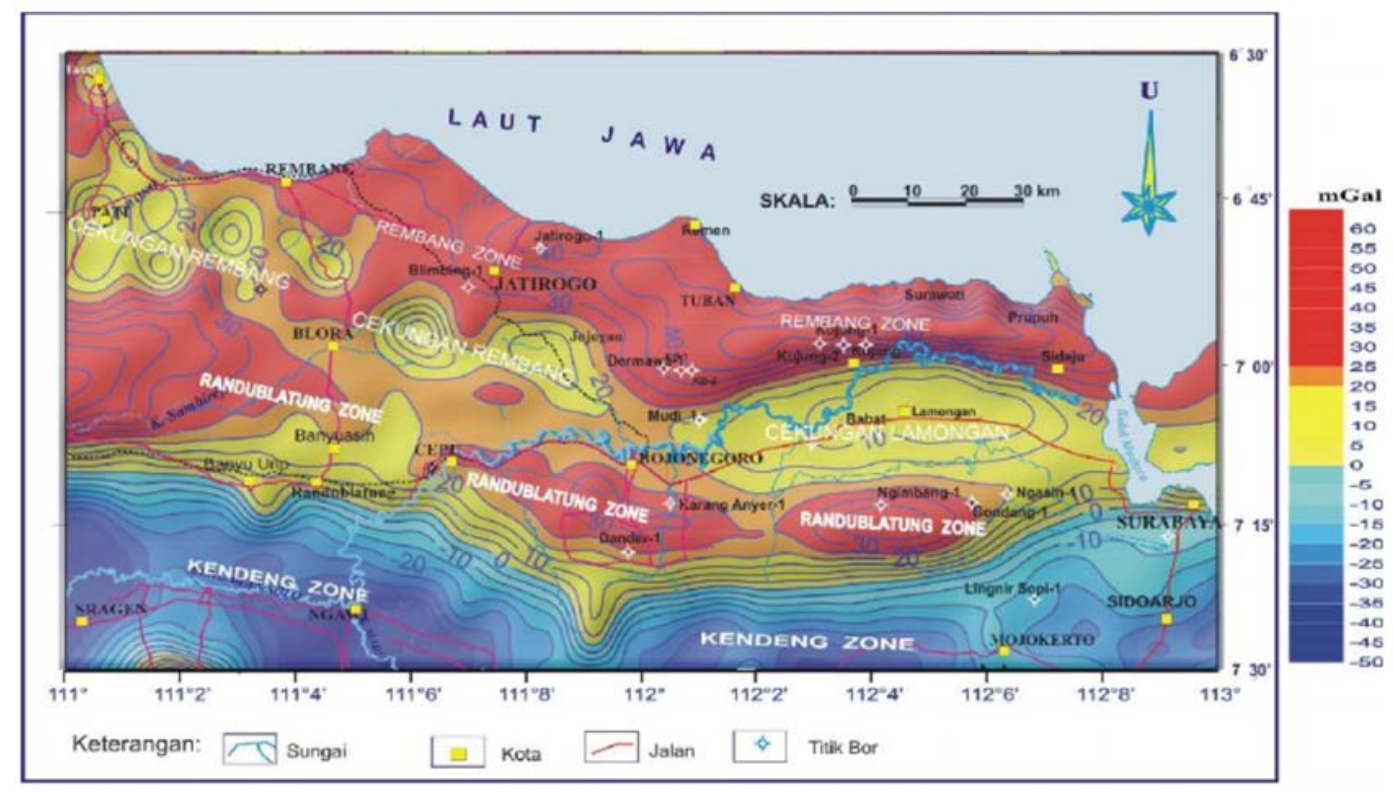

Gambar 3. Peta anomali Bouguer yang memperlihatkan anomali tinggian Zona Rembang dan Zona Randublatung serta rendahan Zona Kendeng (Panjaitan, 2010).

Periode berikutnya adalah periode tektonik kompresional yang diakibatkan oleh penunjaman Lempeng Indo-Australia dibawah Lempeng Eurasia. Peristiwa ini mengaktifkan kembali sesar-sesar di batuan dasar berarah barat - timur menjadi zona sesar mendatar. Tektonik konvergen ini menyebabkan perubahan konfigurasi cekungan menjadi berarah timurlautbaratdaya yang sejajar dengan arah collision suture sepanjang Komplek Lok Ulo Meratus.

\section{KONFIGURASI BATUAN DASAR}

Konfigurasi kedalaman batuan dasar suatu cekungan selain sebagai informasi dalam pemodelan cekungan juga dapat memberikan informasi mengenai sejarah tektonik pembentukan cekungan tersebut. Cekungan Jawa Timur memiliki konfigurasi kedalaman batuan dasar cukup kompleks yang dijadikan dasar pembagian zona fisiografi. Hasil penelitian anomali gaya berat Bouguer (Gambar 3) oleh Panjaitan (2010) memperlihatkan anomali gaya berat tinggian dengan nilai 20-60 mGal pada Zona Rembang dan Zona Randublatung. Anomali ini mengapit anomali rendahan Sub Cekungan Rembang dan Sub Cekungan Lamongan. Zona Kendeng teridentifikasi sebagai struktur cekungan dengan nilai anomali negatif 0-50 mGal.

\section{POLA STRUKTUR UMUM JAWA BAGIAN TIMUR}

Struktur umum di Cekungan Jawa Timur terdiri dari seri sesar normal yang berarah barat daya-timurlaut (arah Meratus), sesar mendatar yang berarah barat-timur (dikenal dengan nama RMKS / Rembang-MaduraKangean-Sakala), dan seri antiklin dan sesar naik yang juga berarah barat-timur (Gambar 4; Sribudiyani dkk, 2003). Sesar mendatar RMKS pada mulanya adalah seri sesar normal yang karena proses inversi pada umur Miosen Awal berubah menjadi sesar mendatar. Sesar normal ini diduga merupakan graben tertua di cekungan ini. Daerah penelitian terletak pada zona sesar ini. Seri sesar normal dengan arah Meratus 


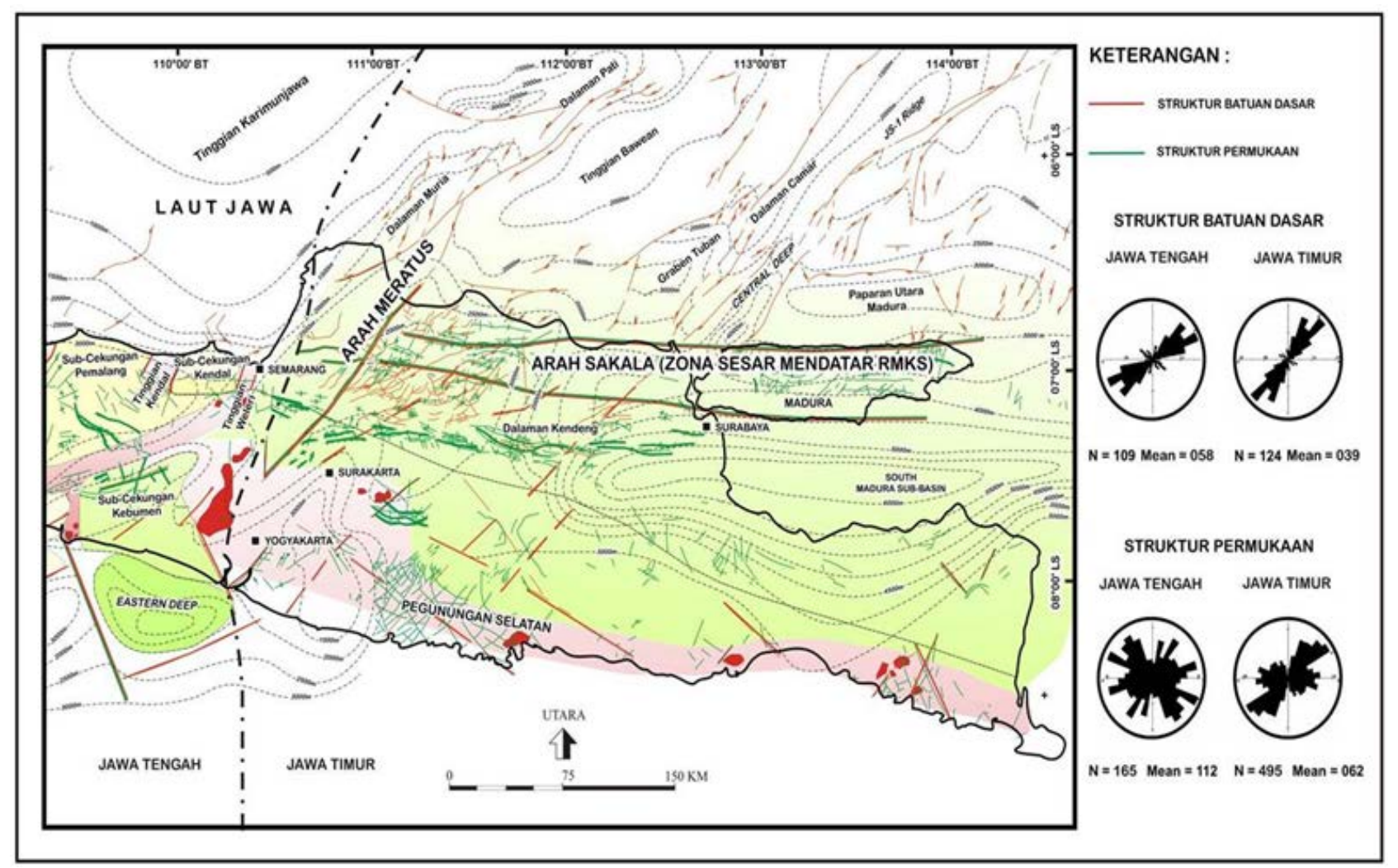

Gambar 4. Pola struktur umum Jawa bagian timur (Sribudiyani dkk., 2003).

membentuk half-graben di cekungan ini sebagai akibat dari subduksi Lempeng Mikro Laut Jawa Timur dengan bagian selatan dari Lempeng Eurasia.

Seri antiklin dan sesar naik terutama berkembang di Zona Kendeng akibat tektonik kompresional pada umur PlioPleistosen. Aktivitas tektonik ini membentuk batas berupa zona sesar naik antara Zona Rembang dan Zona Kendeng. Bidang sesar naik yang nampak memotong sampai ke lapisan berkedudukan horizontal menunjukkan proses pensesaran terjadi paling akhir dibandingkan dengan pembentukan struktur yang lain (arah Meratus dan arah Sakala).

\section{STRATIGRAFI}

Stratigrafi Cekungan North East Java (Gambar 5) dari tua ke muda (Mudjiono dan Pireno, 2001) adalah sebagai berikut:

Siklus Ngimbang (Eosen Tengah-Oligosen

Bawah) Siklus ini merupakan sedimen yang pertama kali terendapkan pada batuan dasar pra-Tersier, secara umum dikontrol oleh arsitektur batuan dasar di bawahnya. Siklus ini disusun oleh Formasi Ngimbang yang terakumulasi di dalam graben dari Eosen Tengah - Eosen Akhir hingga Oligosen Bawah. Formasi Ngimbang bagian bawah disusun oleh seri perlapisan batupasir kuarsa dengan batulempung abu-abu coklat karbonan dengan sedikit sisipan batubara. Sedimen ini diendapkan pada lingkungan payau atau lakustrin. 


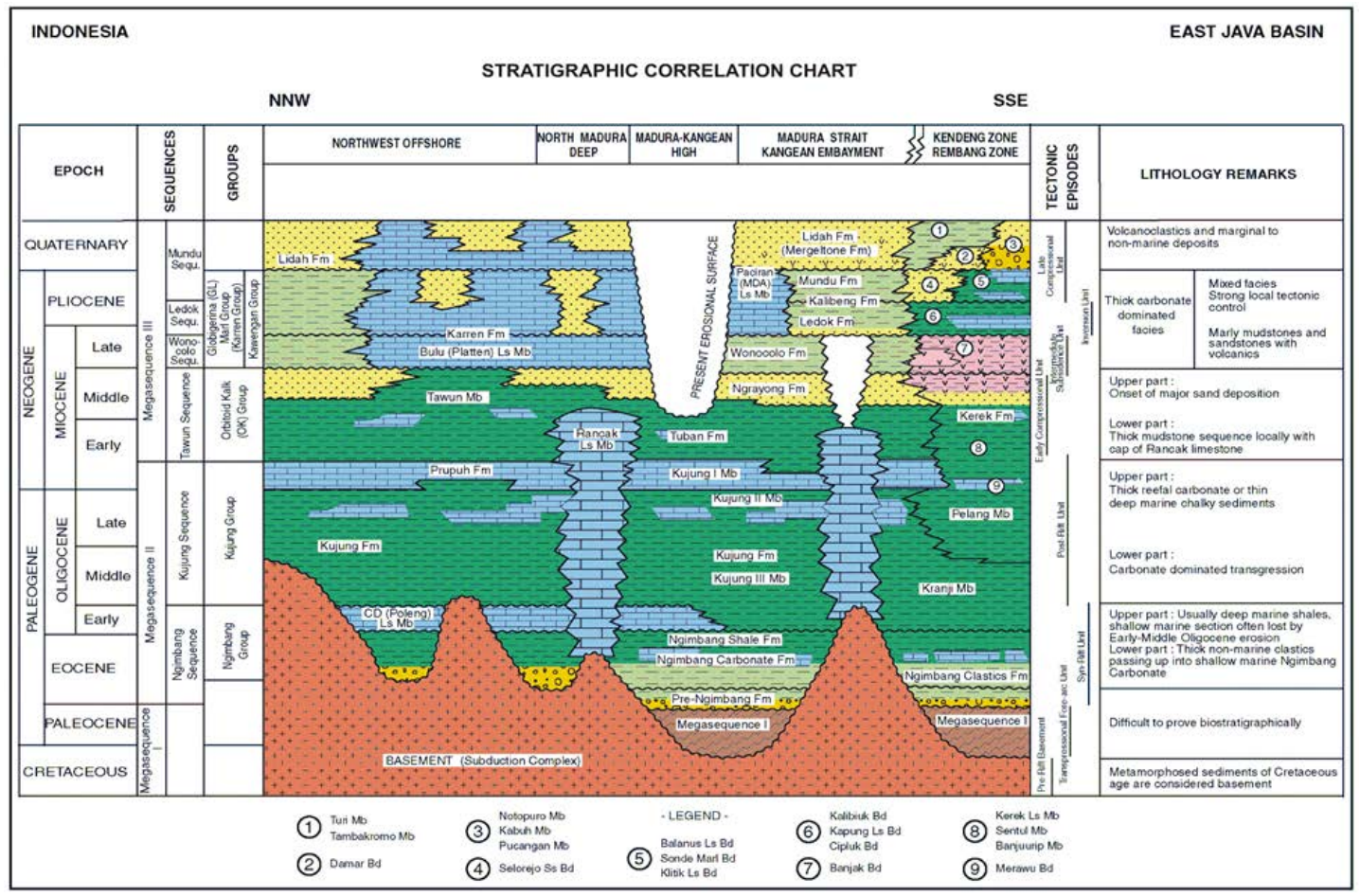

Gambar 5. Tektonostratigrafi Cekungan Jawa Timur (Bransden dan Matthews, 1992).

\section{Siklus Kujung (Oligosen Tengah)}

Tektonik kompresi regional yang berasosiasi dengan eustatik dan tektonik menyebabkan fase regresif baru disertai pengendapan pada Oligosen Tengah. Cities Service membagi bagian ini dari bagian termuda ke bagian tertua sebagai anggota Kujung I, Kujung II, dan Kujung III (Ardhana, 1993, hal.417 dalam Pireno dan Mudjiono, 2001). Bagian dasar Kujung III disusun oleh batuan sedimen klastik regresif dengan ketebalan berkisar dari beberapa kaki pada daerah dekat dengan Sumur KE-17 hingga menebal hingga 2.000 kaki yang berupa batupasir konglomeratan pada daerah Tuban Trough sekitar $100 \mathrm{Km}$ ke arah barat. Anggota Kujung II yang berada di atasnya, merefleksikan perubahan kondisi tektonik yang tadinya aktif menjadi tenang, dan disertai oleh subsidence regional. Sedimen yang terendapkan disusun oleh sikuen transgresif karbonat dangkal batulempung karbonatan. Beberapa carbonate buildup secara lokal tumbuh pada area tinggian yang stabil. Kenampakan seismik yang tidak beraturan dan tidak menerus mencirikan interval Kujung II dan Kujung III di area Paparan Madura Utara, mengindikasikan variasi fasies pengendapan secara lateral yang sangat beragam. Proses pengendapan unit sedimen ini dikontrol oleh pola struktur berarah timur laut-barat daya yang telah terbentuk sebelumnya. Unit Kujung II dan Kujung III merupakan salah satu reservoir target di area Paparan Madura Utara.

Interval Kujung I merupakan bagian batuan karbonat yang tebal (1.300 kaki) dengan sedikit sisipan batulempung. Secara umum merupakan carbonate buildup yang terbentuk sebagai linear fringing reef dan juga patch reef yang terisolasi di paparan karbonat stabil.

\section{Siklus Tuban (Awal Miosen)}

Transgresi Awal Miosen diakhiri oleh event tektonik utama yang disebabkan oleh uplift ke arah baratlaut dan diikuti inisiasi regresif 
pada pertengahan Awal Miosen bagian dari siklus Tuban. Formasi Tuban menunjukkan perubahan yang fundamental dari ekstensif, siklus klastik karbonat hingga klastik yang mendominasi pengendapan yang mengakhiri dominasi pembentukan karbonat. Batas atas yang menandai transisi dari siklus Tuban Awal Miosen hingga Miosen tengah Formasi Ngrayong dapat dikenali dengan adanya input klastik kasar, pasir kaya kuarsa Formasi Ngrayong dari utara. Formasi Tuban disusun oleh interval shale karbonan laut dalam dengan ketebalan 1.500-8.000 kaki dengan sisipan tipis batupasir dan napal. Siklus ini diakhiri oleh batugamping terumbu (Anggota Rancak) yang terakumulasi pada tinggian struktur, beberapa kadang langsung terendapkan langsung di atas unit Kujung I.

\section{Siklus Ngrayong (Miosen Tengah)}

Akumulasi yang sangat luas dari batupasir kuarsa yang terendapkan di atas shale dan batugamping Formasi Tuban. Batupasir Formasi Ngrayong merupakan reservoir penting di daratan Pulau Jawa dan pada area Muriah Trough.

\section{Siklus Wonocolo (Miosen Tengah-Miosen Akhir)}

Sedimen batulempung laut dalam dan napal dengan sedikit sisipan pasir terendapkan secara luas di area lepas pantai, dan dilingkupi oleh akumulasi paparan batugamping dan buildup. Sedimen ini kemudian tersingkap pada Miosen Akhir dan tererosi oleh beberapa seri channel sungai yang kadang memotong langsung hingga interval karbonat. Kontras kecepatan data seismik maupun kecepatan sonik diantara sedimen yang mengisi channel tersebut dibandingkan dengan interval karbonat menyebabkan kesulitan dalam interpretasi struktur kedalaman.

\section{Siklus Miosen - Resen}

Pengendapan dimulai dengan fasa transgresi yang baru dan akumulasi fasies sedimen yang berbeda. Fasies ini termasuk napal dan batupasir yang terombak, globigerinid chalks, batugamping terumbu, dan disertai oleh influks sedimen yang sangat besar yang disusun oleh batupasir vulkaniklastik dari busur gunung api di selatan yang dimulai pada Pliosen Akhir. Kejadian tektonik lokal kemudian mulai mendominasi dan mengontrol semua fasies endapan. Sedimen vulkaniklastik dan globigerinid chalks merupakan reservoir utama pada awal mula penemuan hidrokarbon di daratan Pulau Jawa.

\section{MEKANISME}

\section{TEKANAN LUAP}

\section{TERJADINYA}

Mekanisme pembentukan tekanan luap secara umum dapat dibagi menjadi dua, yaitu loading/disequilibrium compaction dan unloading.

\section{Loading/Disequilibrium Compaction}

Mekanisme ini disebebkan oleh gagalnya fluida dalam formasi untuk keluar dari pori saat proses kompaksi berlangsung. Proses ini terjadi bersamaan dengan sedimentasi batuan yang berlangsung sangat cepat sehingga tekanan akibat beban kolom sedimen di atasnya makin meningkat. Saat fluida gagal keluar dari pori akibat peningkatan tegasan vertikal (overburden), tekanan pori akan meningkat sedangkan tegasan efektif tidak berubah karena tidak ada perubahan porositas. Hal ini dapat dicerminkan melalui profil tekanan-tegasan dimana tekanan pori cenderung sejajar dengan tegasan vertikal pada kedalaman tertentu (Gambar 6). Karakter yang khas dari pembacaan log talikawat akibat mekanisme ini ialah adanya trend bacaan yang konstan pada zona tekanan luap (Gambar 7). 


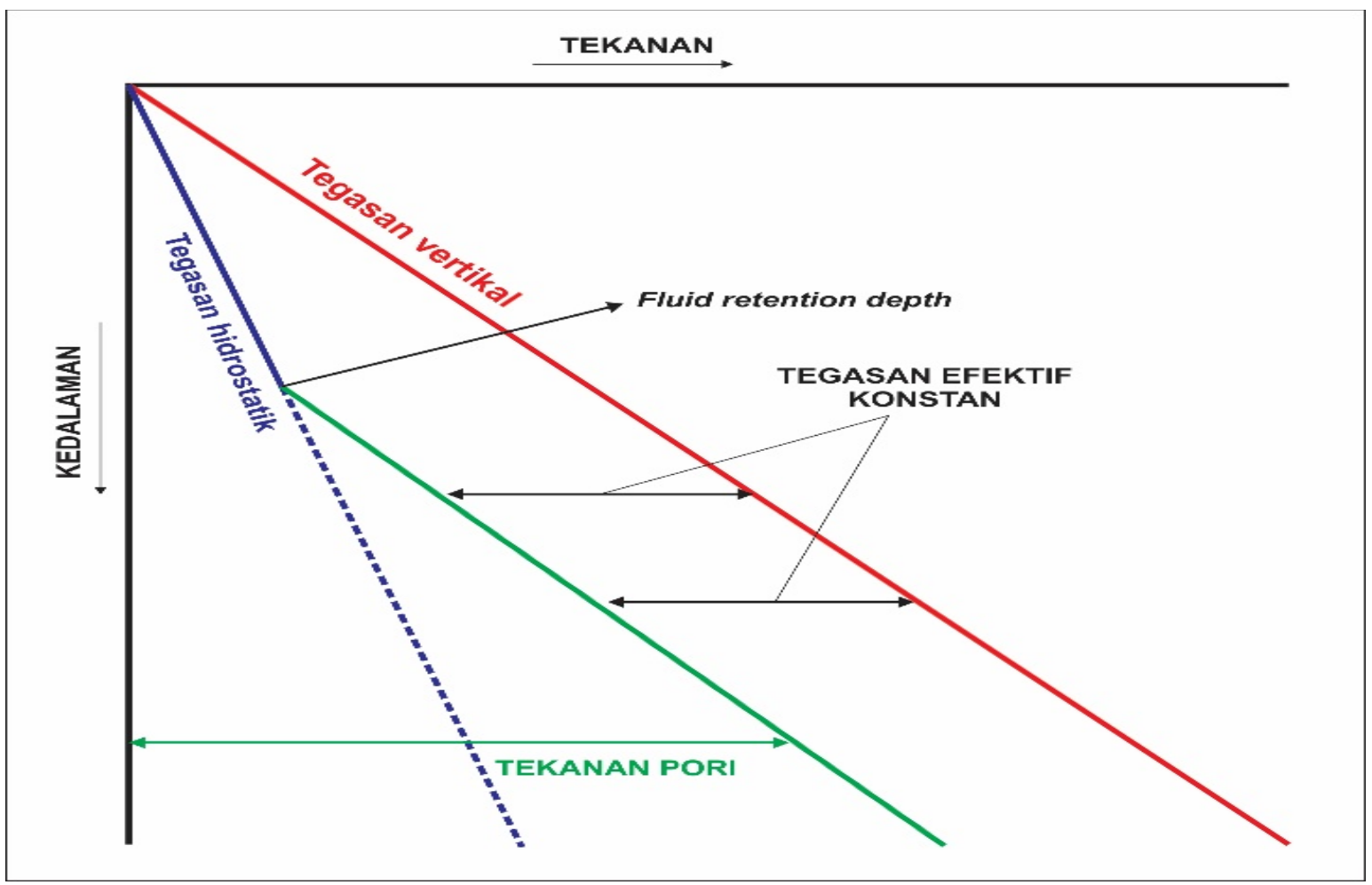

Gambar 6. Profil tegasan-tekanan yang menggambarkan tekanan luap akibat mekanisme disequilibrium compaction. Tekanan pori sejajar dengan tegasan vertical (modifikasi dari Swarbrick, 2002).
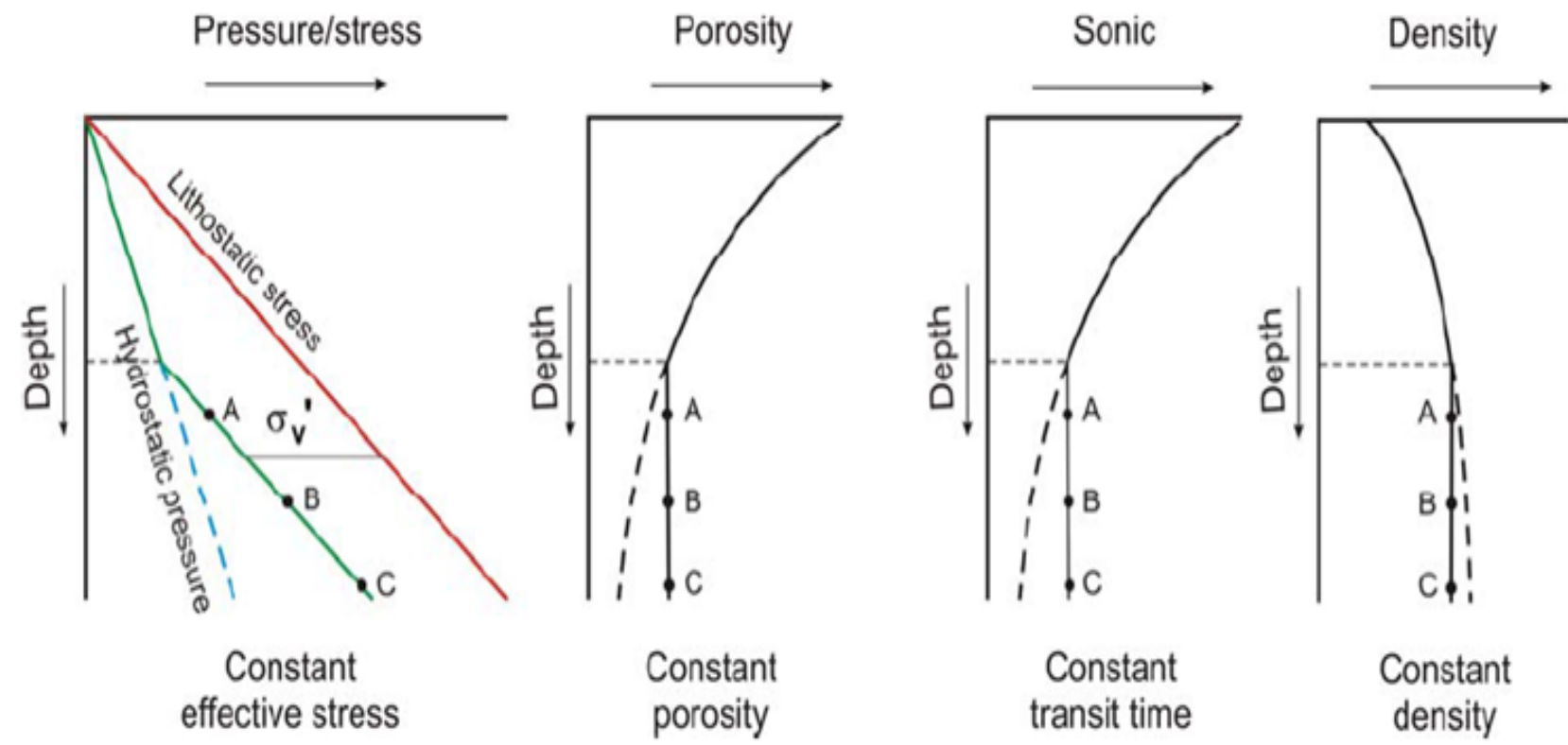

Gambar 7. Ilustrasi respon log talikawat pada zona tekanan luap oleh mekanisme loading (Ramdhan dkk., 2011). 


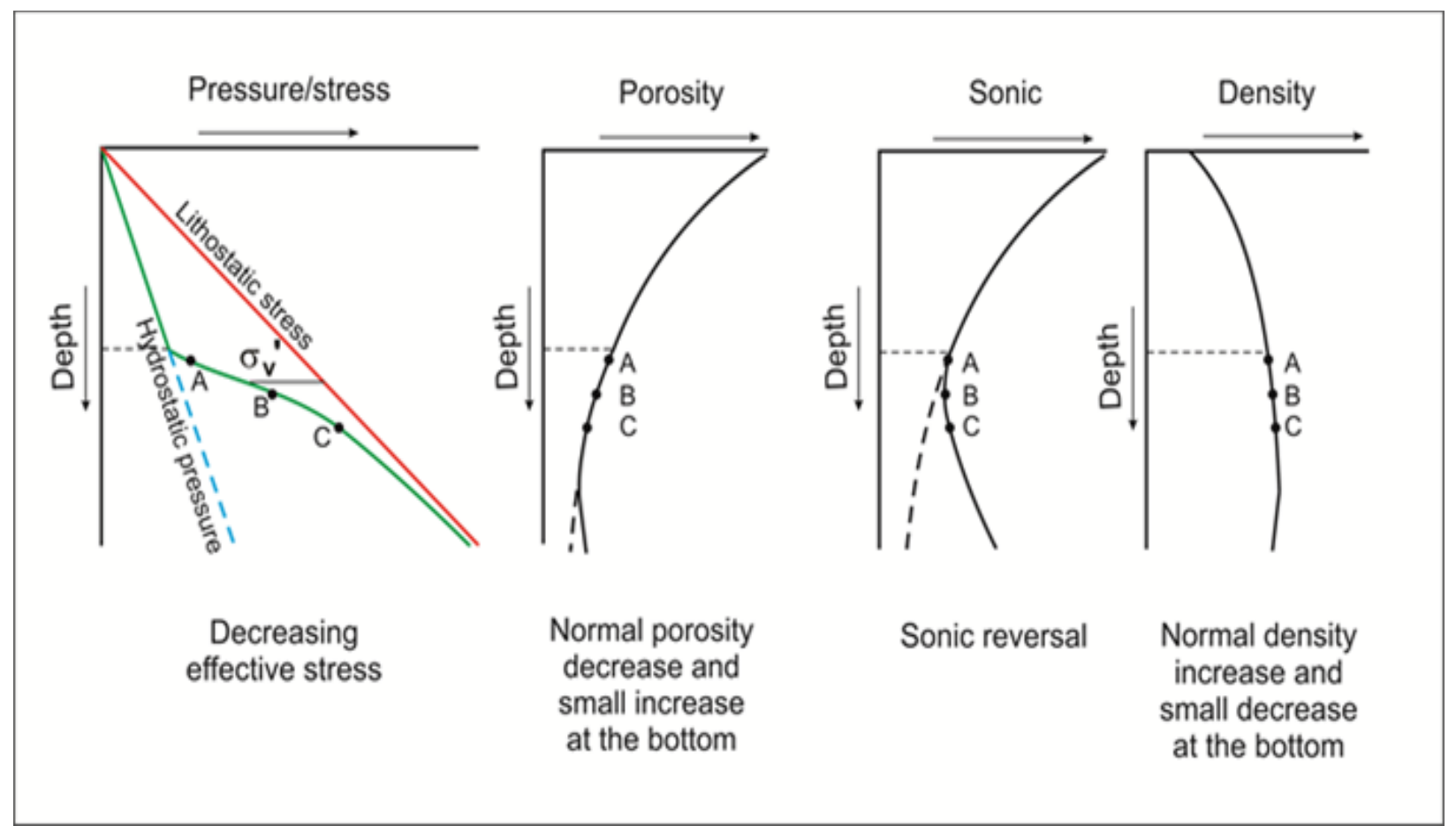

Gambar 8. Respon log talikawat di zona tekanan luap yang disebabkan oleh mekanisme nonloading (Ramdhan dkk., 2011).

\section{Unloading}

Mekanisme unloading terjadi ketika terdapat perubahan tekanan yang diakibatkan oleh adanya pengalihan tekanan dari kontak antar butir kepada fluida dalam pori. Beberapa proses geologi yang dapat menyebabkan terjadinya hal ini adalah diagenesis mineral lempung, proses pematangan kerogen, pengalihan tekanan lateral atau vertikal, dan perubahan tekanan akibat kenaikan temperatur fluida. Karakter log talikawat pada zona tekanan luap akan menunjukkan pembalikan (Gambar 8).

\section{PREDIKSI TEKANAN PORI}

Sebelum melakukan prediksi tekanan pori terlebih dahulu perlu ditentukan trend kompaksi normal batuan. Trend kompaksi normal atau biasa disebut NCT (normal compaction trend) (Gambar 9) dapat diketahui dari data sonik, densitas, maupun resistivitas dari batuan sedimen lempung atau serpih. Kurva trend NCT didapat dari pola nilai densitas, resistivitas, maupun sonik pada kedalaman dangkal yang kemudian diekstrapolasikan hingga kedalaman tertentu. Penyimpangan dari trend ini mengindikasikan adanya gejala tekanan luap.

Penentuan NCT untuk kurva sonik didapatkan menggunakan persamaan berikut:

$\Delta t_{n}=\left(\Delta t_{0}-\Delta t_{m}\right) e^{-b z}+\Delta t_{m}$

keterangan:

$\Delta t_{m}=$ matrix transit time

$\Delta t_{0}=$ surface transit time

$b=$ konstanta

$\mathrm{z}=$ tinggi $\operatorname{kolom}(\mathrm{ft})$. 


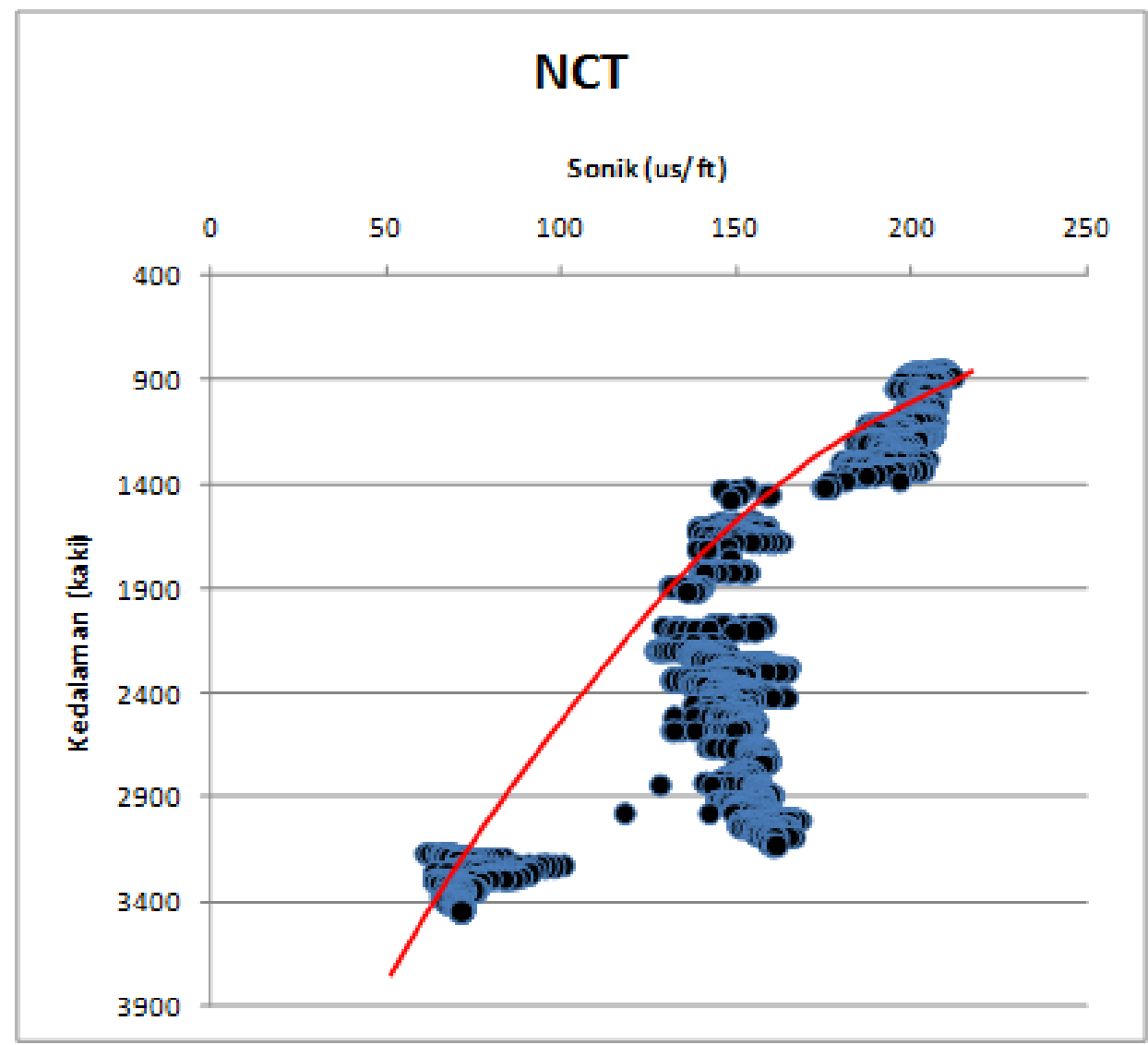

Gambar 9. Kurva NCT dan gejala tekanan luap yang ditandai adanya penyimpangan dari NCT.

Eaton (1975) mengembangkan metode untuk memprediksi tekanan pori berdasarkan data sumur di Teluk Meksiko yang mengalami gejala tekanan luap. Dengan menggunakan data sonik, densitas, dan resistivitas, Eaton merumuskan persamaan sebagai berikut:

1. data log sonic

$$
p=\sigma_{v}-\left(\sigma_{v}-p_{n}\right)\left(\frac{\Delta t_{n}}{\Delta t}\right)^{3}
$$

2. data log resistivitas

$$
p=\sigma_{v}-\left(\sigma_{v}-p_{n}\right)\left(\frac{R}{R_{n}}\right)^{1.2}
$$

3. data dc'exponent

$$
p=\sigma_{v}-\left(\sigma_{v}-p_{n}\right)\left(\frac{D c}{D c_{n}}\right)^{1.2}
$$

keterangan;

$p \quad=$ tekanan pori eaton

$\sigma \quad=$ tegasan vertikal/overburden stress $p_{n} \quad=$ tekanan pori saat nomal hidrostatik

$n \quad=$ kondisi saat hidrostatik normal

$D_{c}=$ nilai dari hasil perhitungan dc'exponent

$R \quad=$ nilai dari resistivitas

$\Delta t \quad=$ nilai dari transit time/log sonic

Swarbrick dkk. (2002) berdasarkan hasil pengamatannya terhadap profil tekanan di bawah fluid retention depth (FRD) pada serpih di Teluk Meksiko dan Asia Tenggara mengajukan suatu metode yang menggambarkan hubungan FRD dengan laju pengendapan. Laju pengendapan yang didapatkan dari ketebalan sedimen dibagi dengan waktu pengendapannya (dalam juta tahun). Berdasarkan hal ini maka dapat ditentukan kisaran FRD atau puncak zona tekanan luap (Gambar 10). 


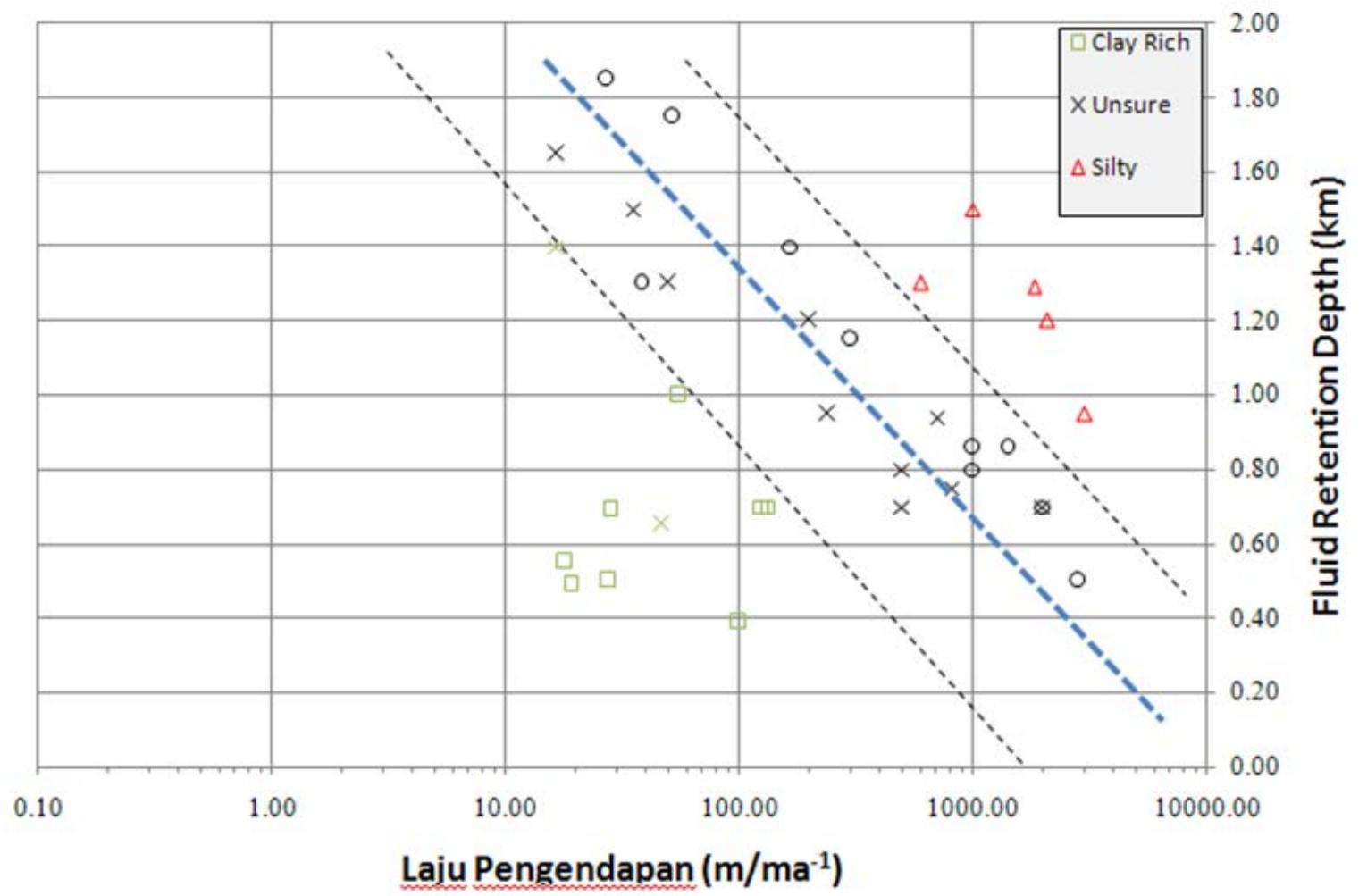

Gambar 10. Hubungan antara laju pengendapan dengan kedalaman FRD (Fluid Retention Depth) pada batuan shale/mudrock (Swarbrick dkk., 2002).

METODE PENGOLAHAN DATA

Sumur-sumur yang diteliti yaitu Sumur A, Sumur B, Sumur C, dan Sumur D (Gambar 10). Pengolahan dan analisis data dilakukan terhadap data shaly interval log gamma ray, density, resistivity, sonic, data mudlog, data MDT/RFT, DST, dan data laporan akhir pengeboran yang tersedia dari masingmasing sumur. Sebagian besar sumur memiliki data (terutama log talikawat) yang cukup lengkap, namun ada juga beberapa sumur yang datanya kurang lengkap.

Pengamatan terhadap respon masing-masing data log memberikan kita gambaran lokasi kedalaman kehadiran zona tekanan luap. Data pengukuran tekanan langsung melalui MDT/RFT maupun DST ditambah data tekanan tidak langsung yang diperoleh dari penggunaan berat lumpur juga membantu dalam mengkonfirmasi kehadiran zona tekanan luap. Mekanisme penyebab tekanan luap dilakukan dengan mengacu kepada metode plot pressure vs depth, plot silang sonic-density oleh Dutta (2002) dan analisis kematangan batuan induk berupa Ro dan Tmax.

\section{ANALISIS DATA}

Pengukuran Tekanan Langsung dan Tidak Langsung

Data pengukuran tekanan langsung diperoleh dari pengukuran DST, FIT, maupun LOT. Dari keempat sumur yaitu A, B, C, dan D, data tekanan hasil pengukuran langsung DST menunjukkan adanya indikasi kehadiran zona tekanan luap (Gambar 11). Data berat lumpur yang digunakan juga menunjukkan adanya indikasi kehadiran zona tekanan luap. Puncak zona tekanan 
luap ini dominan hadir pada kedalaman dangkal sekitar 700 hingga 2.000 kaki DDL. Data tekanan dari pengukuran DST sebagian besar menunjukkan kesesuaian dengan data berat lumpur pemboran yang digunakan. Sebagai pembanding, data tekanan DST Sumur C yang diambil pada interval batugamping Formasi Kujung memiliki nilai yang lebih kecil daripada berat lumpur yang digunakan. Hal ini disebabkan oleh adanya total loss yang mengindikasikan tekanan pori formasi mengalami penurunan sedangkan berat lumpur yang digunakan lebih besar ketika proses pemboran memasuki interval Formasi Kujung.

\section{Analisis Data Log Talikawat}

Data log kecepatan sonik, densitas, dan resistivitas pada keempat sumur yang telah dipisahkan datanya dari litologi selain batulempung atau batulanau cukup memberikan gambaran mengenai lokasi kedalaman zona tekanan luap. Mekanisme penyebab terjadinya tekanan luap dapat disimpulkan dari ketiga trend data log talikawat ini. Apabila data log talikawat memiliki trend yang cenderung konstan seiring bertambahnya kedalaman, maka dapat disimpulkan bahwa mekanisme penyebab tekanan luap ialah akibat disequilibrium compaction. Sedangkan apabila trend data log talikawat cenderung memperlihatkan pembalikan nilai (reversal), maka dapat disimpulkan bahwa tekanan luap disebabkan oleh mekanisme unloading. Pada sumur C, data kecepatan sonik menunjukkan trend yang cenderung konstan seiring bertambahnya kedalaman (Gambar 12). Hal ini mengindikasikan bahwa tekanan luap yang terjadi pada sumur ini disebabkan oleh mekanisme disequilibrium compaction.

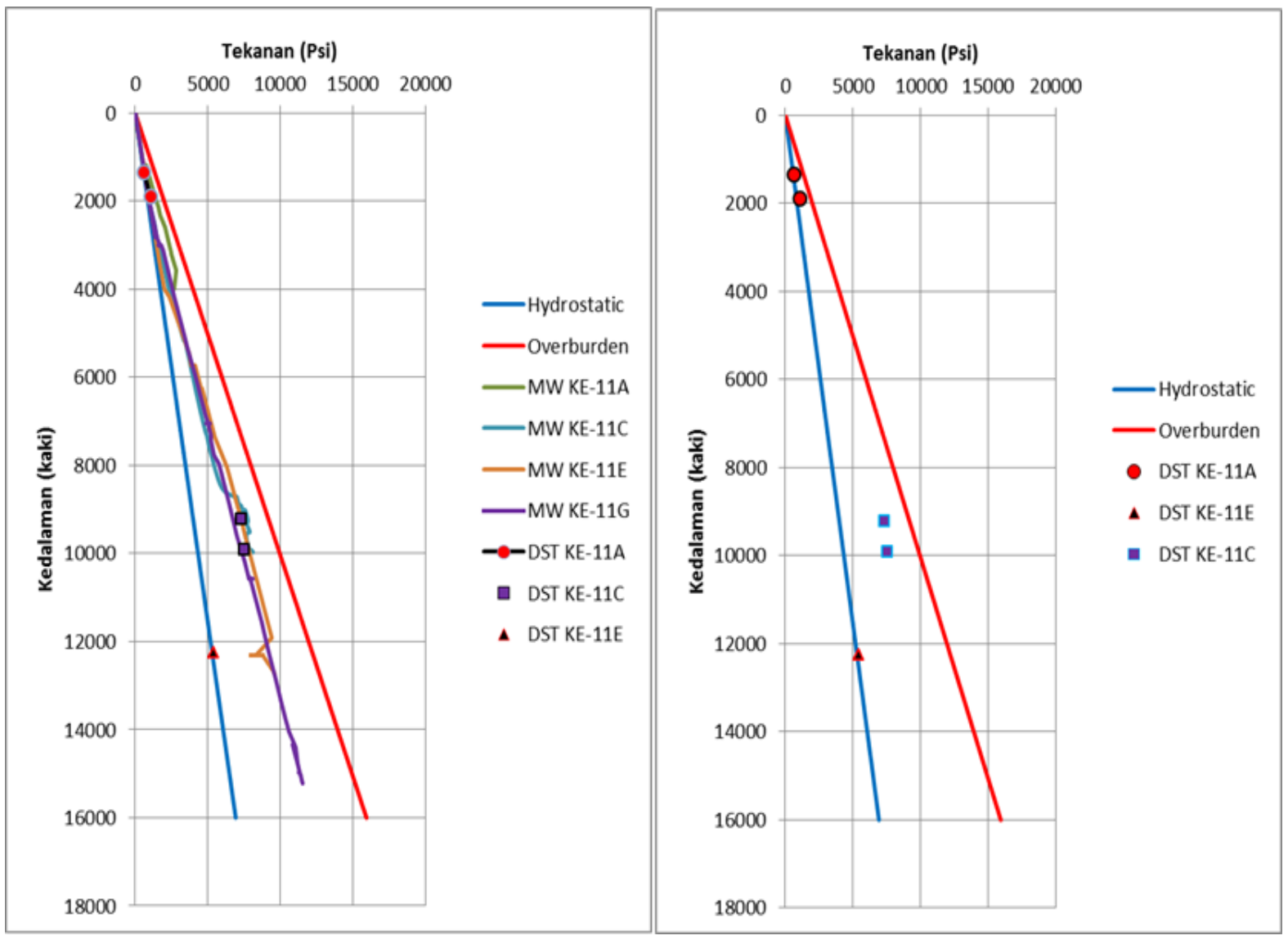

Gambar 11. Pengukuran data tekanan langsung DST dan data berat lumpur pemboran. 

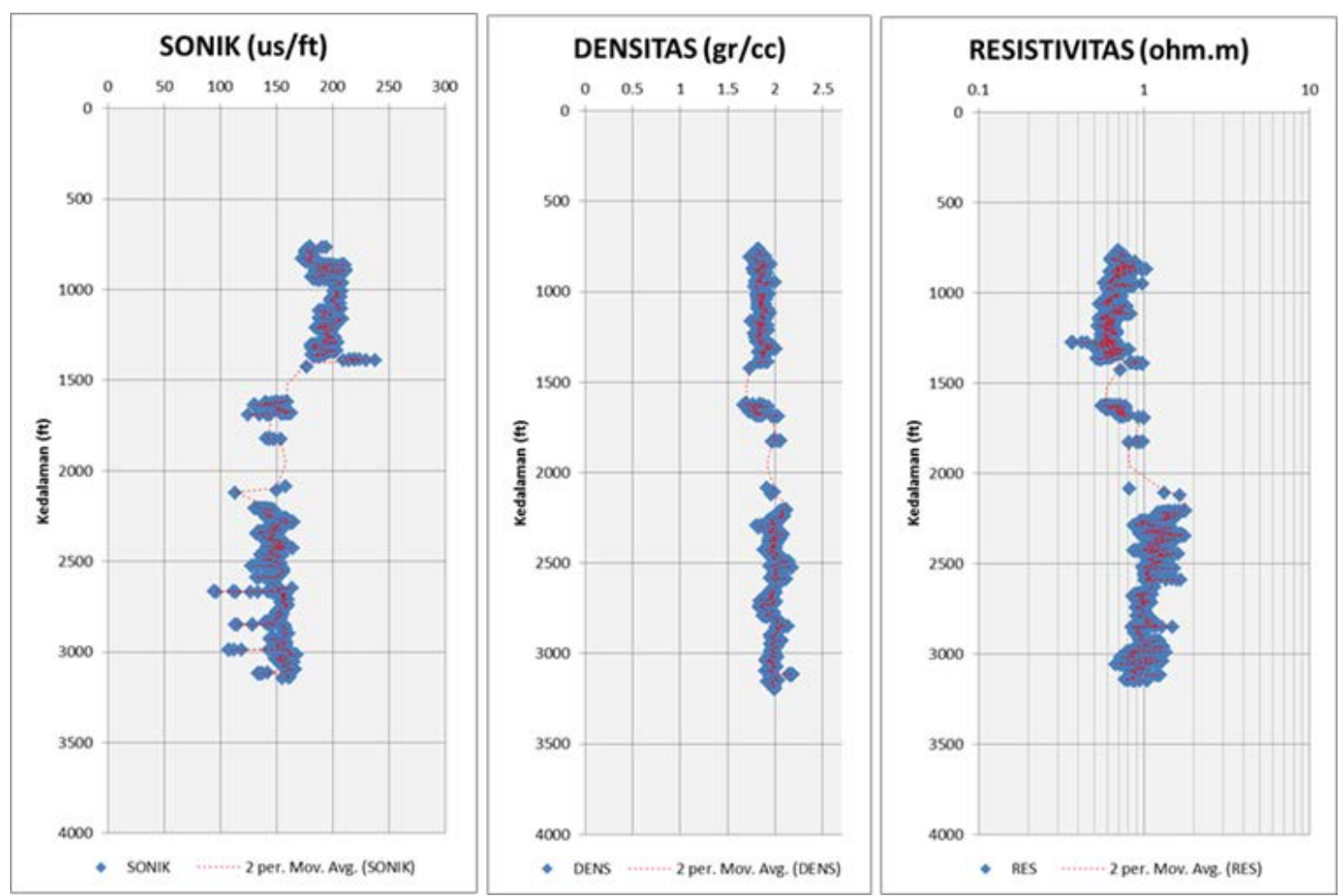

Gambar 12. Log Sumur C yang menunjukan pola log cenderung konstan seiring bertambahnya kedalaman.

\section{Analisis Kematangan Batuan Induk}

Analisis data geokimia batuan induk dari Sumur B, C, dan D (Gambar 13) menunjukkan bahwa batuan induk mulai memasuki jendela kematangan pada kedalaman lebih dari 12.000 kaki. Hal ini ditunjukkan oleh hasil analisis Tmax dari sumur-sumur tersebut yang rata-rata mencapai temperatur $\operatorname{Tmax} 435^{\circ} \mathrm{C}$ di kedalaman tersebut. Batuan induk yang berada pada kedalaman kurang dari 12.000 kaki menunjukkan temperatur yang kurang dari $435^{\circ} \mathrm{C}$.

Hal serupa juga diperlihatkan dari analisis reflektansi vitrinit (Ro) yang menunjukkan batuan induk masih belum matang atau baru memasuki proses pematangan awal.

Berdasarkan data geokimia ini dapat disimpulkan bahwa kemungkinan terbentuknya zona tekanan luap pada kedalaman kurang dari 12.000 kaki akibat mekanisme unloading yang berkaitan dengan proses pematangan kerogen tidak mungkin terjadi. Oleh karena itu penulis menyimpulkan bahwa tekanan luap pada sumur-sumur di daerah penelitian terbentuk akibat mekanisme disequilibrium compaction atau loading.

\section{Analisis Diagenesis Mineral Lempung Smectite-Illite}

Hasil plot silang nilai densitas dan kecepatan sonik di Sumur A dan C (Gambar 14) menunjukkan bahwa nilai-nilai tersebut dominan tersebar sejajar dengan garis smektit atau diantara garis smektit-ilit. Kondisi ini menunjukkan bahwa diagenesis mineral lempung masih dalam tahap awal atau eodiagenesis. Hal ini mengindikasikan bahwa kemungkinan pembentukan zona tekanan luap melalui mekanisme nonloading akibat diagenesis mineral lempung di daerah pengelitian sangatlah kecil. 


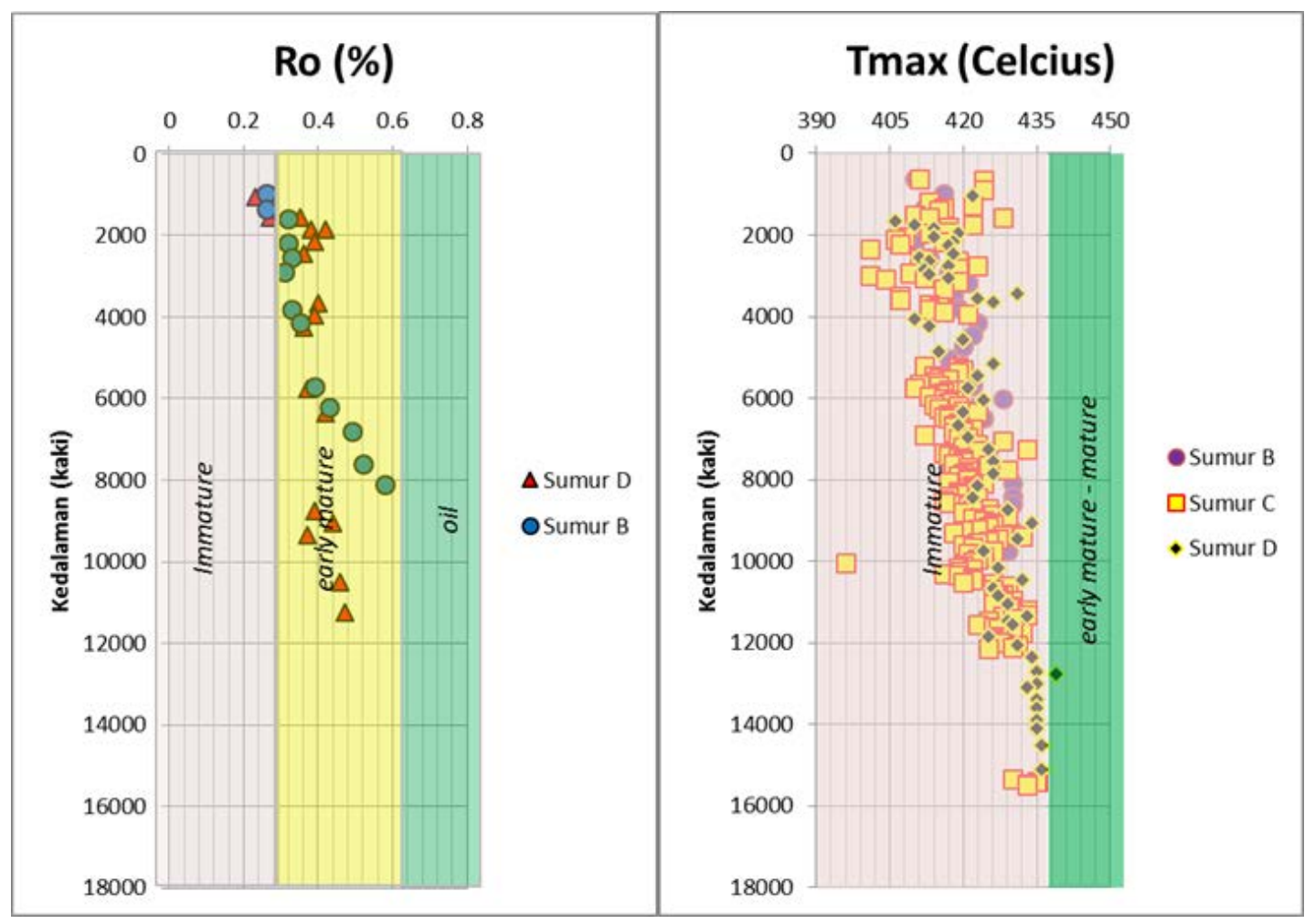

Gambar 13. Analisis kematangan batuan induk di sumur penelitian.

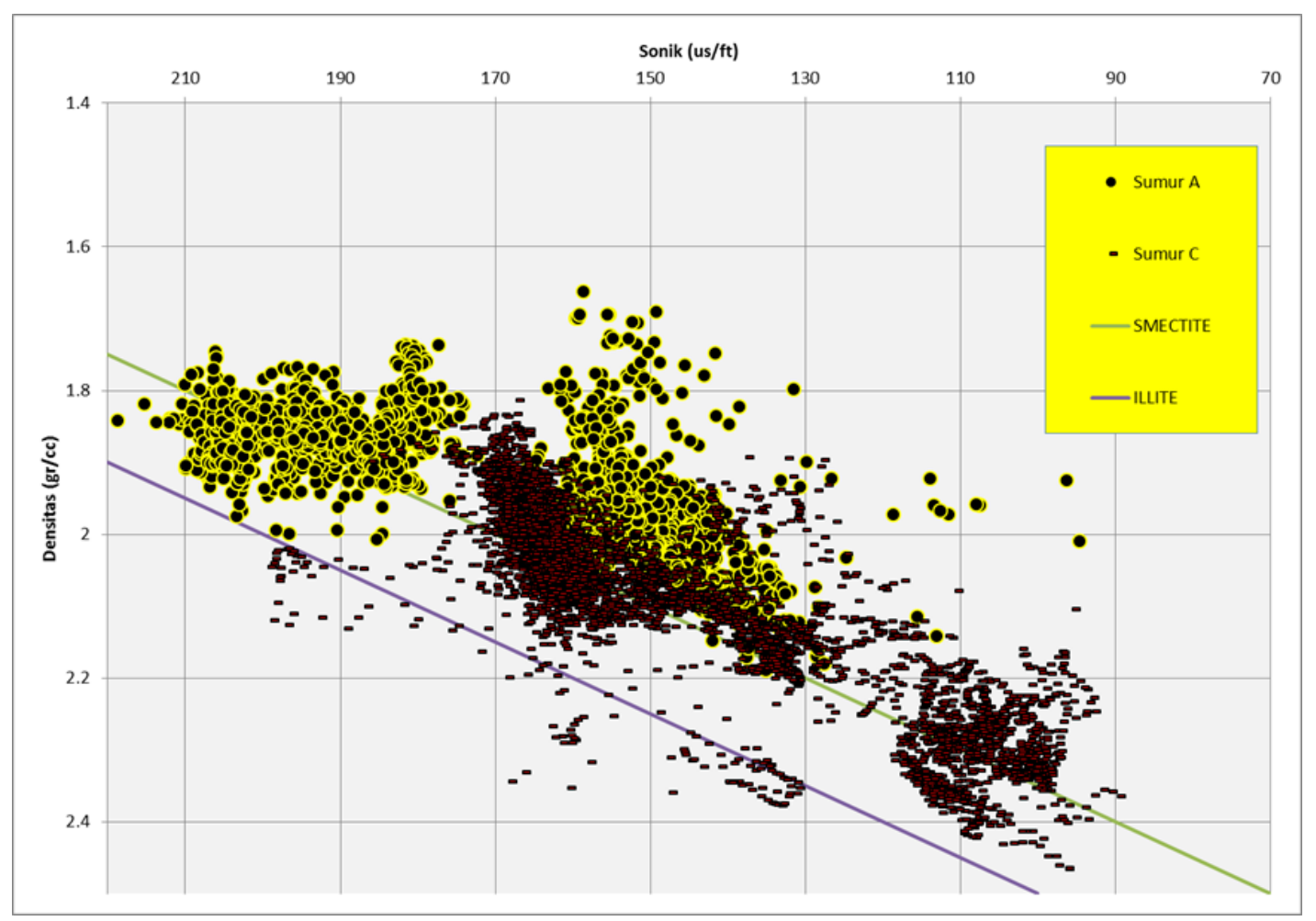

Gambar 14. Plot silang nilai sonik-densitas sumur penelitian. 
Plot silang densitas dan kecepatan sonik memberikan nilai yang tersebar di atas garis ilit. Hal ini kemungkinan menandakan sudah mulai adanya diagenesis mineral lempung dari smectite menjadi illite pada interval kedalaman tersebut. Namun hal ini masih perlu dibuktikan dengan data tambahan seperti data XRD atau SEM. Berdasarkan hasil analisis ini diinterpretasikan bahwa pembentukan tekanan luap di daerah penelitian lebih cenderung disebabkan oleh mekanisme disequilibrium compaction atau loading.

Prediksi Tekanan Pori dan Tekanan luap Analisis tekanan luap menggunakan Metode Eaton menghasilkan nilai eksponen Eaton yang berkisar antara 0,8 hingga 1,2. Nilai ini telah divalidasi dengan data pemboran lainnya. Eksponen Eaton 0,8 hingga 1,2 cukup dapat merepresentasikan tekanan pori formasi pada daerah penelitian (Gambar 15).

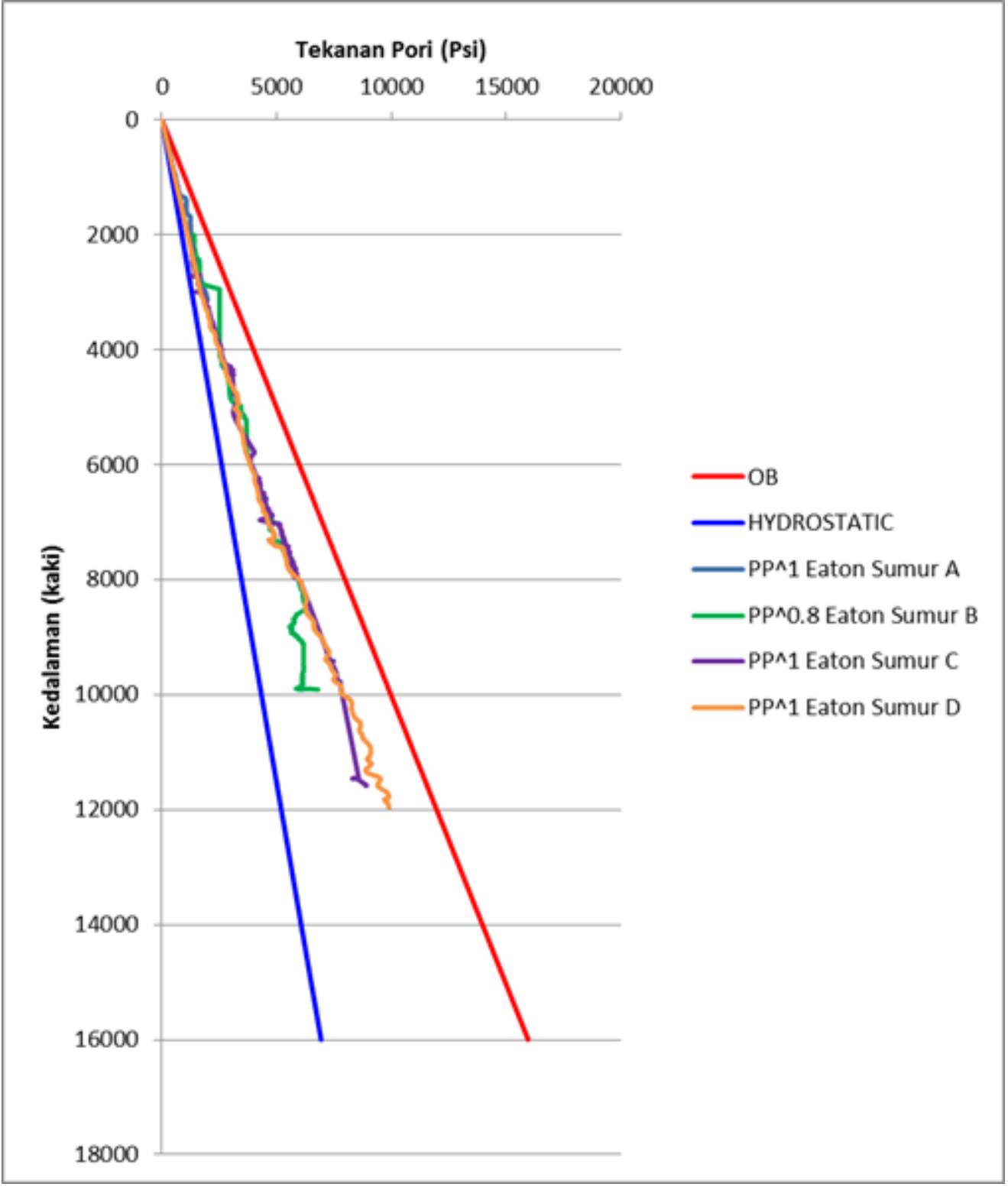

Gambar 15. Rangkuman tekanan pori dan puncak zona tekanan luap berdasarkan Metode Eaton di daerah penelitian. 
Zona tekanan luap yang diprediksi menggunakan Metode Eaton pada Sumur B, D, dan C menunjukkan kedalaman yang tidak terlalu jauh berbeda dengan prediksi menggunakan Metode Swarbrick. Namun pada Sumur A kedua metode tersebut menunjukkan hasil yang berbeda. Prediksi kedalaman zona tekanan luap. Sumur A dengan menggunakan Metode Eaton memiliki nilai yang lebih dangkal dibandingkan dengan menggunakan Metode Swarbrick. Hal ini kemungkinan disebabkan oleh adanya pengaruh erosi yang terjadi pada Sumur A. Proses erosi ini menyebabkan zona tekanan luap terangkat ke kedalaman yang lebih dangkal.

\section{Keterkaitan Tekanan luap dengan Tektonik Regional \\ Lokasi daerah penelitian berada pada Zona Dalaman Kendeng yang saat ini terkompresi}

membentuk lipatan dan sesar anjak dimana sedimen terendapkan dengan sangat cepat. Zona depresi ini melampar secara paralel dengan trend subduksi di Laut Selatan Jawa (Satyana dan Asnidar, 2008). Zona Depresi Kendeng terbentuk pada Neogen sebagai subcekungan belakang busur. Zona depresi ini terbentuk sebagai respon isostatik pengangkatan busur vulkanik selatan pada Oligo-Miosen dan bertindak sebagai cekungan yang mengakomodasi material sedimen. Bagian tengah dari zona depresi ini mengalami penurunan (subsidence) akibat thrust loading yang terjadi pada PlioPleistosen. Namun bagian batas utara dan selatan zona depresi ini mengalami pengangkatan membentuk lipatan dan sesar anjak. Akibat pengangkatan disertai pembentukan lipatan dan sesar anjak, sedimen yang tebal sebagian mengalami

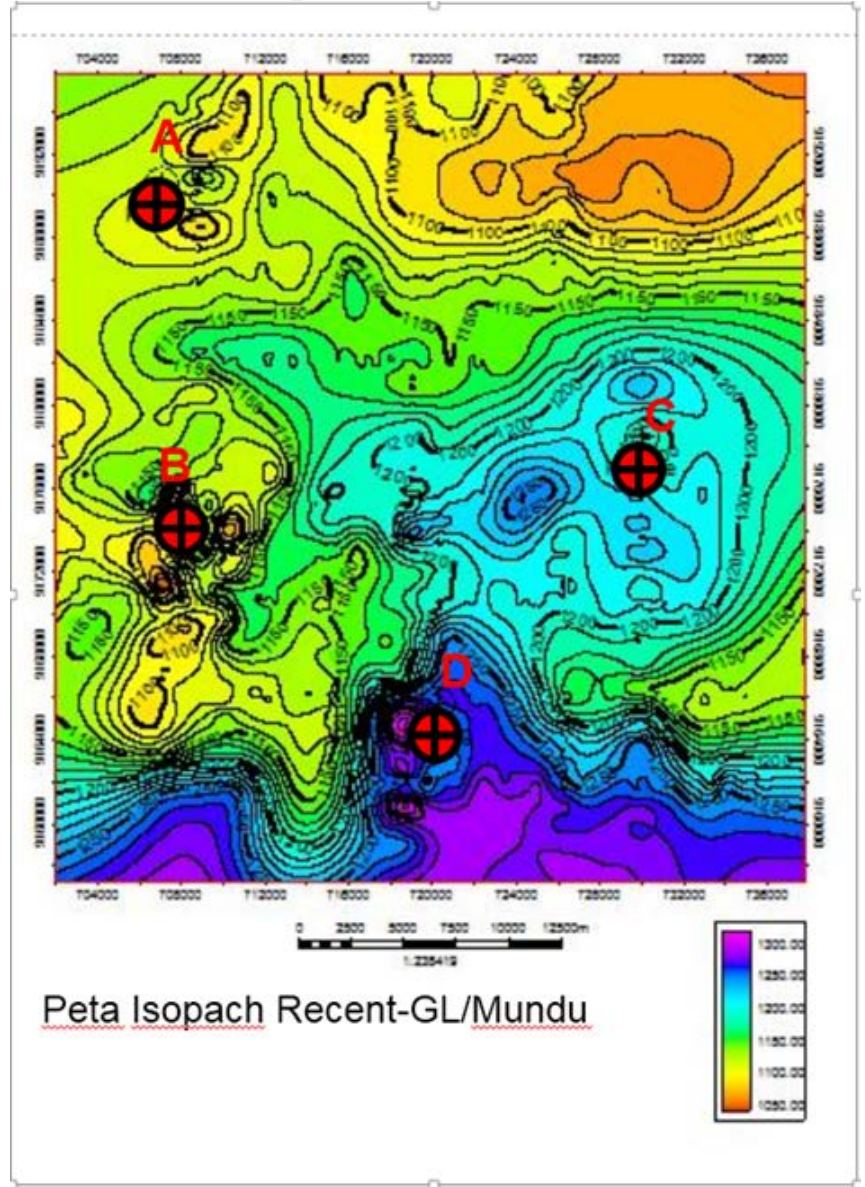

Gambar 16. Isopach GL-MT yang menunjukkan ketebalan sedimen di daerah penelitian. 
aerial exposure dan tererosi masuk ke dalam depocenter. Pada daerah penelitian, depocenter diinterpretasikan berada pada bagian selatan dimana sedimen yang terendapkan sangat tebal seperti yang ditunjukkan oleh peta isopach pada (Gambar 16). Satyana dan Asnidar (2008) menyebutkan ada dua batuan induk (provenance) yang bertindak sebagai sumber material sedimen ke dalam Zona Depresi Kendeng, yaitu: 1) Northern Provenance yang didominasi oleh sedimen laut dangkal hingga terrestrial, bertindak sebagai reservoir di Cekungan Jawa Barat Utara dan Jawa Timur Utara dan 2) Southern Provenance sebagian besar disusun oleh sedimen vulkanik dengan campuran silisiklastik dan karbonat. Sedimen yang sangat tebal dari kedua provenance ini terendapkan dengan sangat cepat ke dalam Zona Depresi Kendeng dengan mekanisme turbidit yang kemudian terkompaksi dengan sangat lambat.

Prediksi tekanan pori dan tekanan luap pada Sumur A, B, C, D dilakukan dengan menganalisis data kecepatan sonik, densitas, dan resistivitas. Trend NCT keempat sumur (Gambar 17) tersebut dibuat dengan menggunakan data kecepatan kecepatan sonic. Namun penentuan trend NCT Sumur C agak sulit dilakukan karena pembacaannya yang tidak menunjukkan nilai normal pada kedalaman dangkal. Berdasarkan profil NCT yang telah dibuat untuk keempat sumur tersebut, dapat terlihat bahwa NCT menunjukkan hasil yang bervariasi. Kurva NCT pada Sumur A menunjukkan nilai NCT yang lebih rendah atau kecepatan yang lebih tinggi pada interval kedalaman yang sama bila dibandingkan dengan ketiga sumur lainnya.

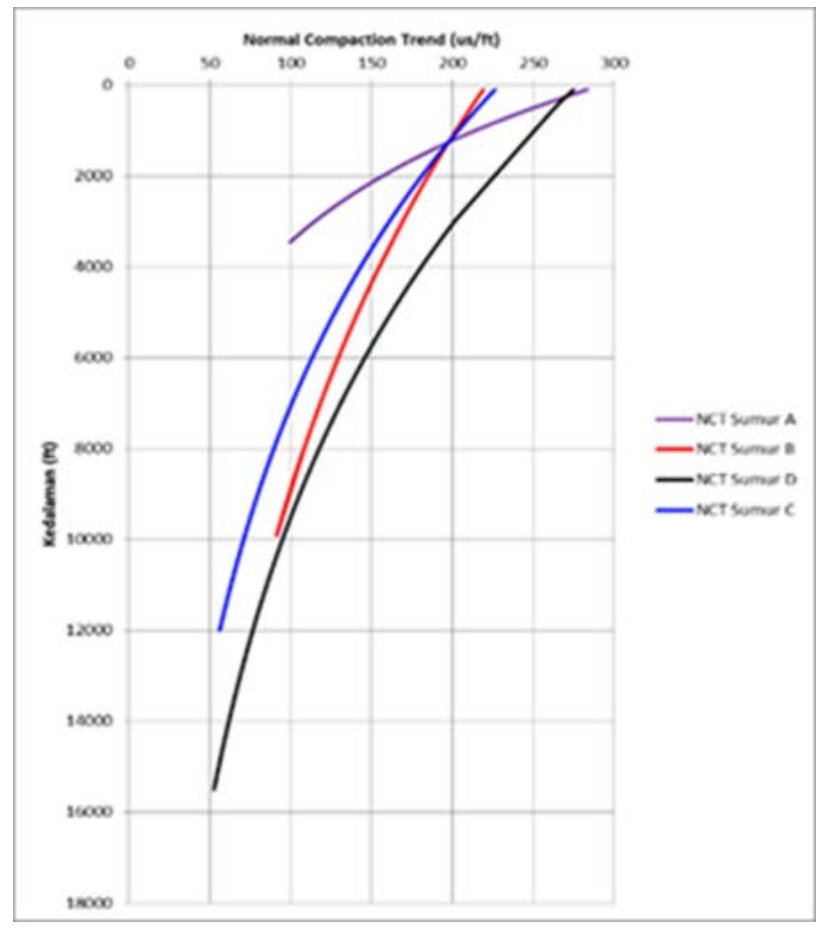

Gambar 17. Kurva NCT keempat sumur penelitian. 

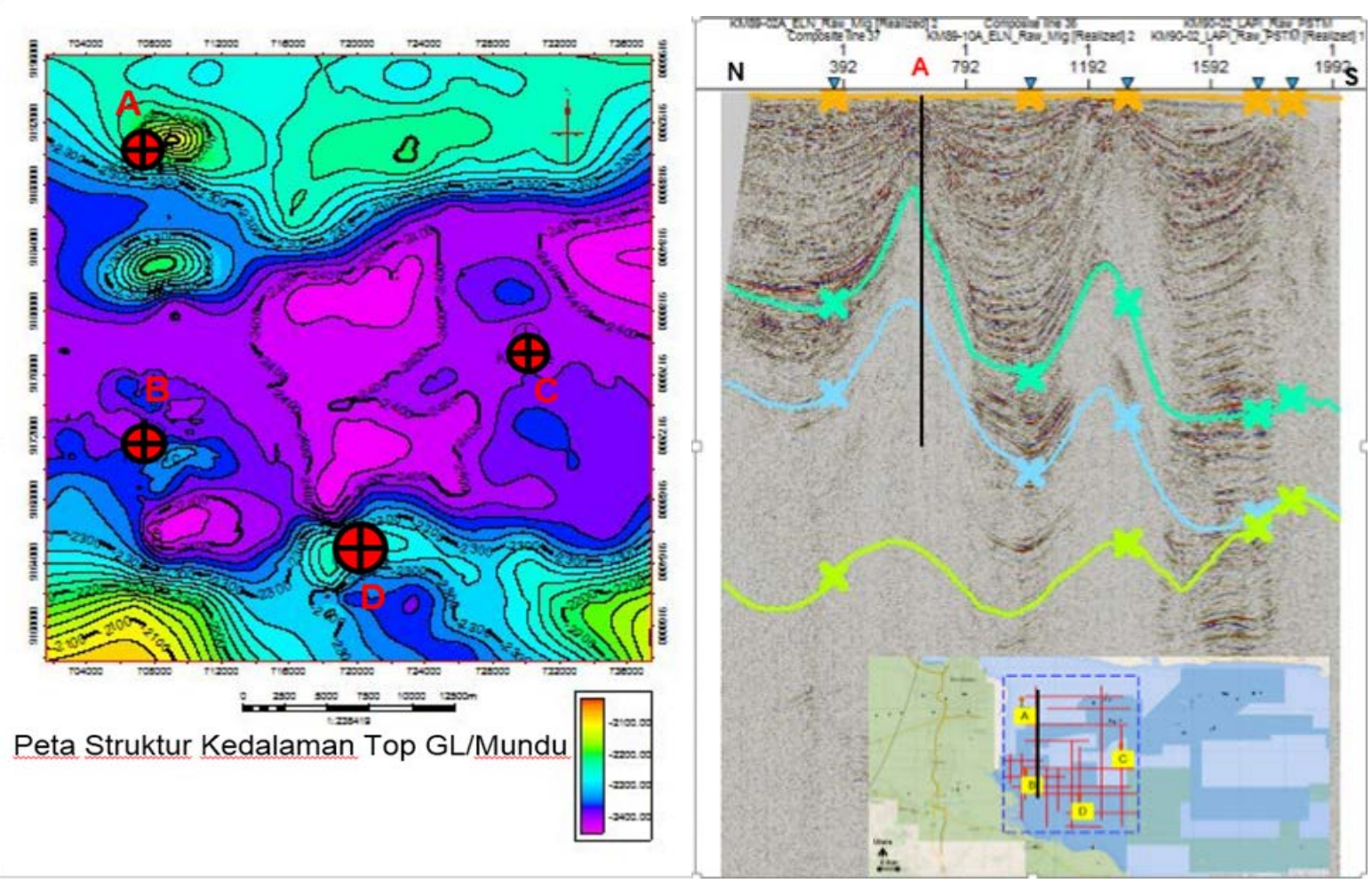

Gambar 18. Peta struktur kedalaman Top GL-Mundu dan penampang seismik arbitrary melalui Sumur A

Hal ini mengindikasikan adanya pengangkatan disertai erosi pada batuan sedimen di Sumur A ini. Penampang seismik dan peta struktur kedalaman (Gambar 18) di daerah penelitian menunjukkan bahwa lokasi Sumur A berada pada daerah tinggian. Berdasarkan data seismik tersebut maka diinterpretasikan bahwa lokasi Sumur A ini kemungkinan terbentuk akibat proses pengangkatan pada Plio-Pleistosen. Hal ini didukung dengan data geologi regional bahwa daerah penelitian termasuk ke dalam Zona Depresi Kendeng yang terbentuk saat Awal Neogen dengan disertai peristiwa tektonik berupa pengangkatan (Satyana dan Asnidar, 2008). Kenampakan antiklin dan sinklin pada penampang seismik menandakan terjadinya tektonik kompresi yang terjadi saat PlioPleistosen hingga saat ini. Selain itu, penampang seismik juga memperlihatkan adanya kenampakan mud diapir yang berkaitan dengan zona tekanan luap.

Hal ini senada seperti yang disampaikan oleh Reksalegora (2015) dalam penelitiannya yang menyatakan bahwa Pulau Madura yang berada dalam zona sesar RMKS mengalami proses pengangkatan dan erosi yang intensif.

Berdasarkan hal ini, dapat juga kita tafsirkan bahwa terdapat kemungkinan selain overburden stress, gaya yang dominan yang juga dapat turut menyebabkan terjadinya tekanan luap ialah horizontal maximum stress. Mengingat rezim tektonik Jawa Timur pada Tersier hingga saat ini didominasi oleh tektonik kompresi yang menghasilkan sesar anjak dan sesar geser (Gambar 19). Hal ini ditunjukkan juga dalam profil tekanan-kedalaman di Sumur A pada (Gambar 20) dimana stress horizontal maksimum lebih besar dibandingkan overburden stress. Hal ini mengindikasikan rezim tektonik yang terjadi berada pada kondisi strike slip. 


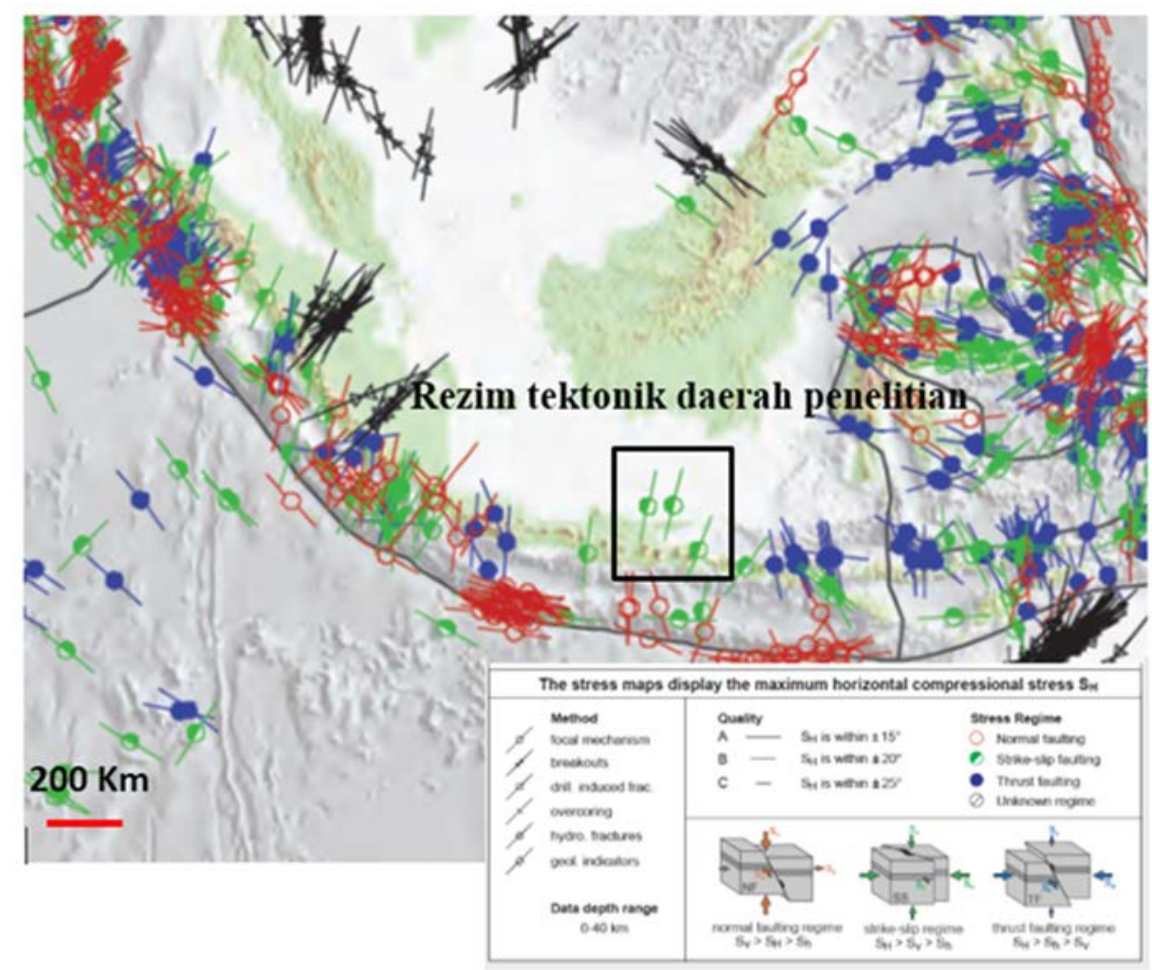

Gambar 19. Rezim tektonik daerah penelitian yang mengindikasikan pola strike slip (Modifikasi dari World Stress Map, 2009).

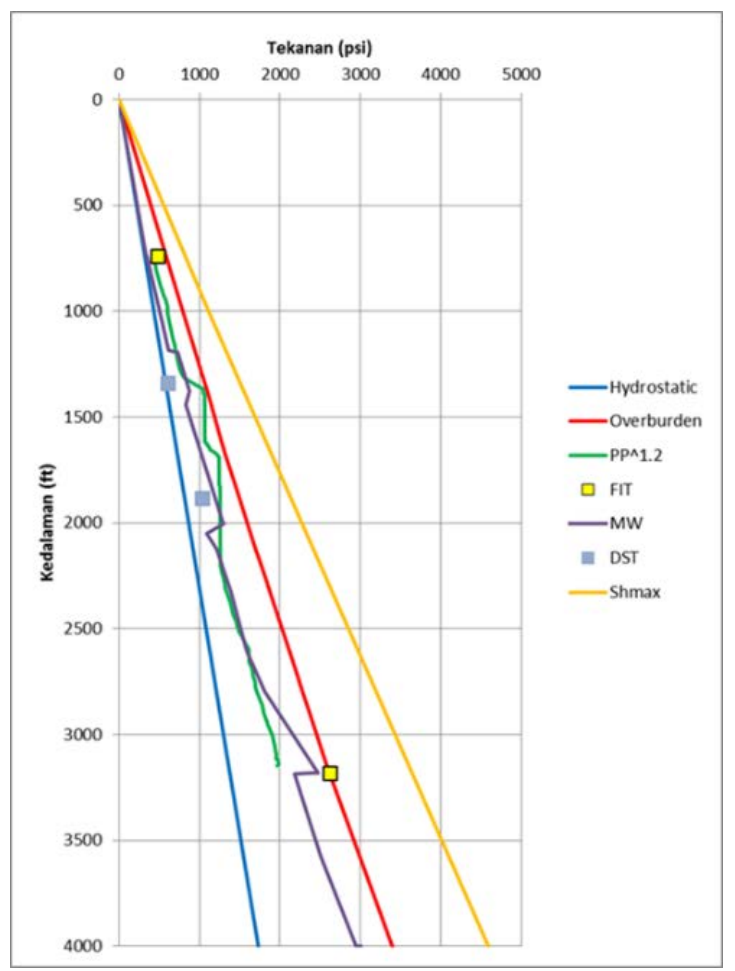

Gambar 20. Profil tekanan vs kedalaman Sumur A yang menunjukkan nilai Shmax yang lebih dominan dibandingkan overburden stress. 


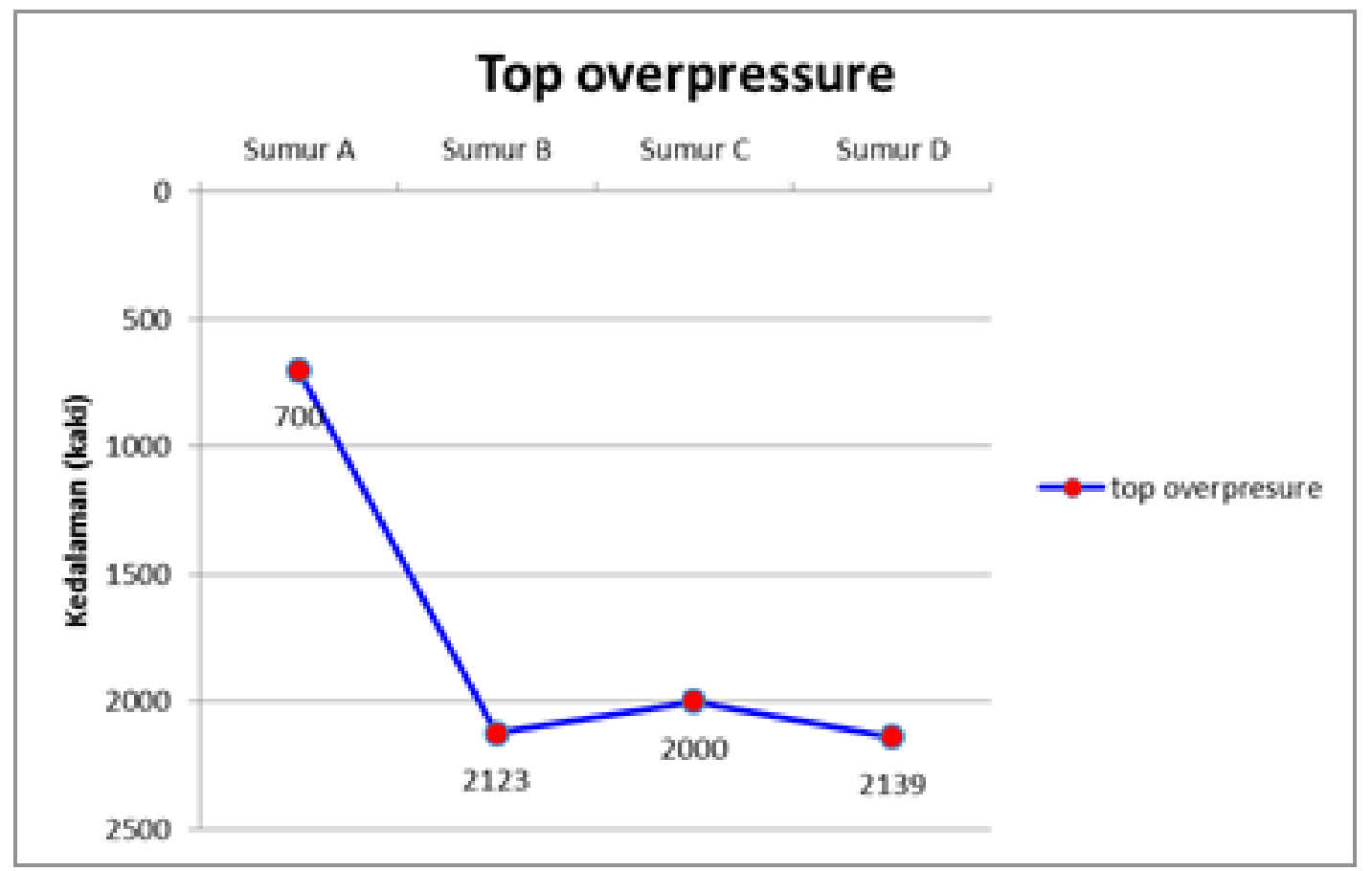

Gambar 21. Perbedaan puncak zona tekanan luap Sumur A dan ketiga Sumur lainnya.

Perbedaan puncak zona tekanan luap pada Sumur A dan ketiga sumur lainnya (Gambar 21) menunjukkan adanya pengaruh proses sedimentasi dan erosi terhadap tekanan pori formasi di daerah penelitian. Proses sedimentasi dan erosi ini sangat berkaitan erat dengan penurunan lapisan batuan dan pengangkatan yang terjadi di daerah penelitian.

\section{KESIMPULAN}

1. Penyebab terjadinya zona tekanan luap di daerah penelitian adalah disequilibrium compaction akibat laju sedimentasi yang sangat cepat.

2. Prediksi zona tekanan luap dengan menggunakan Metode Eaton cukup baik merepresentasikan tekanan pori formasi dan cocok dengan data tekanan hasil pengukuran.

3. Analisis data geokimia menunjukkan bahwa zona tekanan luap di daerah penelitian bukan disebabkan oleh mekanisme nonloading terkait pematangan kerogen.
4. Perbedaan kedalaman zona tekanan luap pada daerah penelitian disebabkan oleh proses penurunan (subsidence) yang berasosiasi dengan sedimentasi dan proses pengangkatan yang berasosiasi dengan proses erosi. Proses ini erat kaitannya dengan tektonik regional Cekungan Jawa Timur Utara.

5. Penyebaran zona tekanan luap di daerah penelitian dikontrol oleh laju sedimentasi, proses pengangkatan, dan erosi.

\section{REFERENSI}

Bransden, P.J.E. dan Matthews, S.J. (1992). Structural and Stratigraphic Evolution of The East Java Sea, Indonesia, Proceeding, Indonesian Petroleum Association, 21st Annual Convention, 417-453.

Dutta, N.C. (2002). Deepwater geohazard prediction using prestack inversion of large offset P-wave data and rock model. The Leading Edge, 21, 193198. 
Eaton, B. (1975). The Equation for Geopressure Prediction from Well Logs, Society of Petroleum Engineers of AIME, SPE 5544, 11p.

Heidbach, O., Tingay, M., Barth, A., Reinecker, J., Kurfeß, D., Müller, B. (2009). World Stress Map 2nd Edition based on WSM Database Release 2008, Helmholtz Centre Postdam-GFZ Germany Research Centre for Geosciences. IHS (2016): EDIN. https://edin.ihsenergy.com/edingis

Mudjiono, R. and Pireno, G.E. (2002). Exploration of the North Madura Platform, offshore East Java, Indonesia. In: Indonesian Petroleum Association, Proceedings $28^{\text {th }}$ Annual Convention, 707-726.

Panjaitan, S. (2010). Prospek Migas pada Cekungan Jawa Timur dengan Pengamatan Metode Gaya Berat, Buletin Sumberdaya Geologi Volume 5 No. 3, 168-181

Pertamina BPPKA (1996). Petroleum Geology of Indonesian Basins, Principles, Methods, and Aplication Volume IV East Java Basins, 1 p., Pertamina BPPKA, Jakarta.

Reksalegora, Sena Warman (2015). Analisa Penyebab Terjadinya Tekanan luap dan Prediksi Tekanan Pori di Daerah Daratan dan Lepas Pantai Madura Selatan. Bandung, Tesis. Institut Teknologi Bandung.

Satyana, A.H. dan Asnidar (2008). Mud Diapir and Mud Volcanoes in Depressions of Java to Madura; Origins, Natures, and Implications to Petroleum System, Proceedings, Indonesian Petroleum Associations, $32^{\text {nd }}$ Annual Convention.

Sribudiyani, Muchsin, N., Ryacudu, R., Kunto, T., Astono, P., Prasetya, I., Sapiie, B., Asikin, S., Harsolumakso, A.H., Yulianto, I. (2003). The Collision of The East Java Microplate and Its Implication for Hydrocarbon Occurences in The East Java Basin, Proceedings, Indonesian Petroleum Association, 29 ${ }^{\text {th }}$ Annual Convention.

Swarbrick, R.E., Osborne, M.J. \& Yardley, G.S. (2002). Comparison of Overpressure magnitude resulting from the main generating mechanisms. In: Huffman, A.R. \& Bowers, G.L. (eds.) Pressure Regimes in Sedimentary Basins and their Prediction. AAPG, Tulsa, Memoir 76, 1-12. 